\title{
Effect of Different Soil Treatments on Dissipation of Chlorantraniliprole and Dehydrogenase Activity Using Experimental Modeling Design
}

\author{
Mohamed E. I. Badawy*, Ahmed F. El-Aswad, Maher I. Aly \& Mohamed R. Fouad \\ Department of Pesticide Chemistry and Technology, Faculty of Agriculture, 21545-El-Shatby, Alexandria \\ University, Alexandria, Egypt
}

*Corresponding Author: Mohamed E. I. Badawy, Department of Pesticide Chemistry and Technology, Faculty of Agriculture, 21545-El-Shatby, Alexandria University, Alexandria, Egypt

\begin{abstract}
Laboratory studies were conducted to investigate the dissipation behavior of chlorantraniliprole $(C A P)$ insecticide in two common types of Egyptian soils (Alluvial and Calcareous) with different conditions and treatments. The side effect of CAP was also tested on soil dehydrogenase (DHase) activity. The CAP was analyzed by HPLC and its dissipation followed the first order kinetics. Type of soil, amendment (wheat straw), temperature, sterilization and time of incubation were selected to design the experiments by Minitab software. The residues dissipated below the limit of quantification (LOQ) of $0.074 \mu \mathrm{g}$ after 60 days of the application at $50 \mu \mathrm{g} / \mathrm{g}$ soil in both soils. The half-life $\left(t_{0.5}\right)$ value was ranged from 7.52 to 11.55 days in Alluvial soil (A) and from 9.01 to 11.63 days in Calcareous soil (B). The modeling showed that the experimental data could be adequately adapted in a second-order polynomial model with a multiple regression coefficient $r^{2}>0.70$ for the prediction of dissipation and $t_{0.5}$. The result proved that the enzyme activity was significantly decreased in all treatments compared with the controls at 1 and 3 days of incubation then it was gradually increased at 7, 10, 15 and 30 days of incubation.
\end{abstract}

Keywords: Chlorantraniliprole; HPLC; Dissipation; Soil; Modeling; Half-life; Dehydrogenase.

\section{INTRODUCTION}

The fate of pesticides in soils has received increasing attention in recent decades because of concerns about the potential impacts on surface and groundwater quality and agricultural products (Gavrilescu 2005; Khan 2016; Kookana 2010). Among the many processes that rule the vital fate of pesticides in the environment, the degradation process plays an essential role (Khan and Manchur 2017). In order to assess the degradability or dissipation of pesticides in different soils, it is imperative that we understand their kinetics of degradation mechanisms in soils. Currently, many pesticides are widely used in agriculture; however, there is a lack of information on important environmental parameters such as half-life values (the time for $50 \%$ of initial residues to be dissipated) for a number of pesticides under various climatic and soil conditions in different Egyptian soils (Bajeer et al. 2016; ElSebae 1989; Mansour 2004).

Chlorantraniliprole (CAP), a new anthranilic diamide insecticide, is developed worldwide by E.I. Du Pont de Nemours and Company, Inc. with high biological activity for foliar applications at rates of 10 to $60 \mathrm{~g}$ chlorantraniliprole/ha in many crops against all Lepidoptera and some Coleoptera, Diptera and Isoptera species, such as codling moth, apple fruit moth and free leaf living larvae (Bassi et al. 2007; Cameron et al. 2015). However, the field dissipation rates of this insecticide are broadly variable, depending on the type of soil and other factors affecting the degradation process. In all conditions, an efficient degradation occurred owing to direct light absorption and microbial degradation processes involving either clays or natural organic matter (OM) contents (Mountacer et al. 2014).

The residue of a novel insecticide, CAP was extracted from soil with acetonitrile by QuEChERS (Quick, Easy, Cheap, Effective, Rugged and Safe) method or solid phase extraction cartridge (Dong et al. 2011; Zhang et al. 2012). An effective analytical method for the residue analysis of CAP recently have been reported by high performance liquid chromatography (HPLC) (Xu et al. 2010). Average CAP recovery from soil at different levels (5 or 10,40 , and $100 \mu \mathrm{g} / \mathrm{kg}$ ) ranged from 74.9 to $97.5 \%$, with intra-day relative standard deviation (RSD) values of 1.9-11.3\% and inter-day RSD values of 4.7-10.4\%. The $\mathrm{t}_{0.5}$ of CAP changed from 12.6 to 23.1 days in soil (Dong et al. 2011). 
CAP is not stable in basic solutions. In acetonitrile and tris buffer solution of $\mathrm{pH} 9$, the concentration of CAP $20.6 \mu \mathrm{M}$ dropped by $27 \%$ after three weeks of incubation in the dark at room temperature. The transformation of CAP in water is a result of chemical and photochemical reactions, greatly influenced by the $\mathrm{pH}$ and the bases present in the water (Lavtižar 2015). In addition, the residue and persistence behavior of CAP in soil were studied. The residue was dissipated following first order kinetics. The $\mathrm{t}_{0.5}$ value of CAP in various soil types was 3.66 day (Malhat et al. 2012), 8.36 day (Sharma et al. 2014b), 16.0 day (Zhang et al. 2012) and about 1 year (Brugger et al. 2010).

CAP has an excellent profile of safety to non-target organisms such as earthworms and soil microorganisms (Sharma et al. 2014b). Many studies have shown that pesticides use have some effect on soil biology. However little information is available concerning the effect of pesticides on soil enzyme activities in semi arid zone of Africa including Egypt (Naré et al. 2014; Singh and Singh 2005). The soil Dehydrogenase (DHase) showed an inhibitory effect with increase of pesticide doses. Dose of fonofos on the level of $1 \mu \mathrm{g} / \mathrm{g}$ soil of pesticide caused 5-21\% inhibition of enzymatic activity, whilst ten times higher doses resulted in $17-44 \%$ drop of activity in comparison to the control (Stepniewska et al. 2007). The mixture of pethoxamid and terbuthylazine contained in the herbicide Successor in doses greater than $0.73 \mathrm{mg} / \mathrm{kg}$ of soil caused a strong inhibition of DHase, catalase, urease, acid phosphatase, alkaline phosphatase and arylsulphatase (Tomkiel et al. 2014).

Therefore, the objective of this study was to investigate the residual behavior and the dissipation kinetics over time of CAP in two types of the common Egyptian soils (Alluvial and Calcareous) with different conditions and treatments. The study was experimentally designed using Minitab software with obtaining some models to predict the dissipation percentage of CAP in soils tested at different conditions. This work therefore attempts to use computer-based Minitab software or modeling studies to develop appropriate models that could estimate or predict a reasonable the persistence of the CAP insecticide as a function of its degradation half- life under different conditions and treatments. Moreover, the effect of CAP on soil DHase activity was investigated.

\section{MATERIALS AND METHODS}

\subsection{Soil and Chemicals}

Two types of the common Egyptian soils were tested in the present study. Alluvial soil (soil A) was obtained from Agricultural Research Station, Abis and Calcareous soil (soil B) from Bangar Elsokar region. The samples were collected from the top $(0-30 \mathrm{~cm})$ layers of the soil profiles from different locations. Technical grade chlorantraniliprole (CAP), 3-bromo- $N$-(4-chloro-2-methyl-6-(methylcarbamoyl)phenyl)-1-(3-chloropyridin-2-yl)-1H-pyrazole-5-carboxamide, was obtained from DuPont Corp., Wilmington, DE ( $(\geq 98 \%$ purity). Triphenyltetrazolium chloride (TTC), triphenylformazan (TPF), water (HPLC grade), methanol (HPLC grade), acetonitrile (HPLC grade) and PTFE syringe filter $(0.2 \mu \mathrm{m})$ were purchased from Sigma Aldrich Co. (Spruce Street, Louis., MO, USA). Anhydrous magnesium sulfate, sodium chloride, sodium acetate and activated charcoal were purchased from El-Nasr Pharmaceutical Chemicals Co. (El Gomhoriya St., Abu Zaabal Area 491, Qalyub, Egypt) and used without further purification. Other commercial solvents including acetonitrile, acetone, butanol, chloroform, dimethyl formamide (DMF), ethanol, and methanol were purchased from Algomhoria Chemical Co., Alexandria, Egypt.

\subsection{Apparatus and Instrumentation}

UV-Vis Spectrophotometer (Thermo Corporation, Nicolet, evolution 100, Germany), Ultra Microplate Reader (Robonik, PVT. LTD), Orbital shaker (Bibby Steril, LTD, UK), Centrifuge (Model 90-1 UK), water bath (LSB 0155, Korea), Water Distillatory (DESA 0035, Eu), Incubator (JSSI100T, Korea), Autoclave (YX-280A, China), pH meter (Milwaukee, MARTN, Italy) and Digital balance (ViBRA AJ-320E, 0.01-150 g, JAPAN) were used. The instrument used for the quantification of CAP was an Agilent 1260 HPLC Infinity system (Germany) equipped with an Agilent variable wavelength ultraviolet detector (VWD). The system consisted of quaternary gradient solvent pump to control the flow rate of the mobile phase and an autosampler for automatic injection, a vacuum degasser and a column oven $\left(5-80^{\circ} \mathrm{C}\right)$.

\subsection{Soil Analysis}

Soil samples were air-dried, ground and passed through a 2-mm sieve prior to use. The soil texture was determined by the hydrometer method (Gee et al. 1986). Soil $\mathrm{pH}$ was measured using $0.01 \mathrm{M}$ calcium chloride $\left(\mathrm{CaCl}_{2}\right)$ in a 1:2 w/w soil:solution slurry. The organic content (OC) and organic 
Effect of Different Soil Treatments on Dissipation of Chlorantraniliprole and Dehydrogenase Activity Using Experimental Modeling Design

matter $(\mathrm{OM})$ content were determined by dichromate oxidation according to the Walkley-Black method (Nelson et al. 1996). Electrical conductivity (EC) was determined by EC meter. Other physicochemical properties of the tested soils including water holding capacity, total carbonate percentage and soluble cations and anions concentration (meq/L) were measured (Table 1).

Table 1. Physicochemical properties of the tested soils

\begin{tabular}{|c|c|c|c|}
\hline \multicolumn{2}{|l|}{ Properties } & Soil A & Soil B \\
\hline \multicolumn{2}{|l|}{ Type } & Alluvial & Calcareous \\
\hline \multicolumn{2}{|l|}{ Texture class } & Sandy clay loam & Sandy loam \\
\hline \multicolumn{2}{|l|}{ Water holding capacity (WHC, mL) } & 46.00 & 35.00 \\
\hline \multicolumn{2}{|l|}{$\mathrm{EC}(\mathrm{m} \mathrm{mohs} / \mathrm{cm})$ at $25^{\circ} \mathrm{C}$} & 1.32 & 2.33 \\
\hline \multicolumn{2}{|l|}{ Soil pH } & 8.25 & 8.20 \\
\hline \multicolumn{2}{|l|}{ Organic matter content $(\%)$} & 3.31 & 1.32 \\
\hline \multicolumn{2}{|l|}{ Total carbonate $(\%)$} & 7.87 & 40.09 \\
\hline \multirow[t]{4}{*}{ Soluble cations conc. (meq/L) } & $\mathrm{Ca}^{++}$ & 3.80 & 8.80 \\
\hline & $\mathrm{Mg}^{++}$ & 5.00 & 7.00 \\
\hline & $\mathrm{Na}^{+}$ & 9.40 & 15.30 \\
\hline & $\mathrm{K}^{+}$ & 0.50 & 2.40 \\
\hline \multirow[t]{4}{*}{ Soluble anions conc. (meq/L) } & $\mathrm{CO}_{3}^{--}$ & 1.60 & 1.60 \\
\hline & $\mathrm{HCO}_{3}^{-}$ & 2.60 & 3.40 \\
\hline & $\mathrm{Cl}^{-}$ & 8.50 & 16.50 \\
\hline & $\mathrm{SO}_{4}^{--}$ & 0.60 & 1.80 \\
\hline
\end{tabular}

\subsection{Experimental Design}

Response surface methodology was used to design the experiment to optimize the dissipation of CAP in different soil treatments (Box and Behnken 1960) by using Minitab 17.1.0.0 software (Minitab Inc., USA). The design consists of replicated center points and a set of points lying at the midpoints of each edge of the multidimensional cube that defines the region of interest (Box and Behnken 1960). The experimental ranges for the parameters included soil type (soil A and B), soil amendment (wheat straw), temperature $\left(25\right.$ and $50^{\circ} \mathrm{C}$ ), sterilization (sterilized soil and non-sterilized soil) and time of incubation (15 and 30 days) were chosen to study the widest possible range of possibilities. The software modeled the experiments and reduced the time and the cost as well as increased the precision. A total of 12 experiments was carried out since a two-level full create factorial design with zero center point were used (Table 2).

Table 2. Experimental design of chlorantraniliprole dissipation in soil using Minitab software

\begin{tabular}{|c|c|l|c|l|c|}
\hline Treatment & Soil type & Amendment & Temperature & \multicolumn{1}{|c|}{ Sterilization } & Incubation time (day) \\
\hline 1 & Soil B & Wheat straw & $25^{\circ} \mathrm{C}$ & Sterilized & 30 \\
\hline 2 & Soil B & Without & $50^{\circ} \mathrm{C}$ & Non-sterilized & 30 \\
\hline 3 & Soil A & Wheat straw & $50^{\circ} \mathrm{C}$ & Non-sterilized & 30 \\
\hline 4 & Soil A & Wheat straw & $25^{\circ} \mathrm{C}$ & Sterilized & 10 \\
\hline 5 & Soil A & Without & $50^{\circ} \mathrm{C}$ & Sterilized & 30 \\
\hline 6 & Soil B & Without & $25^{\circ} \mathrm{C}$ & Non-sterilized & 30 \\
\hline 7 & Soil B & Wheat straw & $50^{\circ} \mathrm{C}$ & Sterilized & 10 \\
\hline 8 & Soil A & Without & $50^{\circ} \mathrm{C}$ & Sterilized & 10 \\
\hline 9 & Soil A & Without & $25^{\circ} \mathrm{C}$ & Non-sterilized & 10 \\
\hline 10 & Soil B & Wheat straw & $25^{\circ} \mathrm{C}$ & Non-sterilized & 10 \\
\hline 11 & Soil B & Wheat straw & $50^{\circ} \mathrm{C}$ & Non-sterilized & 30 \\
\hline 12 & Soil A & Without & $25^{\circ} \mathrm{C}$ & Sterilized & \\
\hline
\end{tabular}

\subsection{Preparation of Standard Stock Solutions}

A standard stock solution of CAP at $1000 \mathrm{mg} / \mathrm{L}$ was prepared by dissolving $100 \mathrm{mg}$ of the compound into a volumetric flask and the volume was completed to $10 \mathrm{~mL}$ with acetonitrile. Working solution of $50 \mathrm{mg} / \mathrm{L}$ was diluted to reach the required final concentration. All the standard solutions were stored at $-20^{\circ} \mathrm{C}$ in glass bottles with Teflon-lined screw caps. The various concentrations of CAP were spiked in the soil for recovery study.

\subsection{Soil Treatment}

A weight of $150 \mathrm{~g}$ of each soil type was placed in $500-\mathrm{mL}$ glass bottle and treated with tested pesticide (50 $\mu \mathrm{g}$ a.i./g soil, equivalent with five folds of the recommended rate). Three replicates were 
made for each treatment. The stock of the pesticide was mixed with distilled water equals to $60 \%$ of water holding capacity (WHC) of the soil. The solution was added to the soil to reach the adequate concentration of $50 \mu \mathrm{g} / \mathrm{g}$. All bottles were incubated throughout the experimental period. The experimental parameters were considered according to experimental MINITAB design.

\subsection{Determination of CAP in Soil by HPLC}

\subsubsection{Determination of wavelength of maximum absorbance and HPLC-standard calibration curve}

The standard solutions of CAP were scanned in the range of 190-340 nm against mobile phase as a blank using a UV-Visible spectrophotometer (Thermo Corporation, Nicolet, evolution 100, Germany). CAP showed maximum absorbance at $273 \mathrm{~nm}$ (Figure 1A). This wavelength was selected for the determination of CAP by HPLC. For preparation of stock solution for HPLC, standard of CAP was dissolved in methanol $(100 \mathrm{mg} / \mathrm{L})$, considering standard purity, by accurately weighing individual analytical standards into volumetric flasks, dissolving and diluting them to volume with methanol and stored at $4^{\circ} \mathrm{C}$ in the dark. Working standard solutions were prepared daily by appropriately diluting multiple stock solutions with acetonitrile (Johnson and Pepperman 1995).
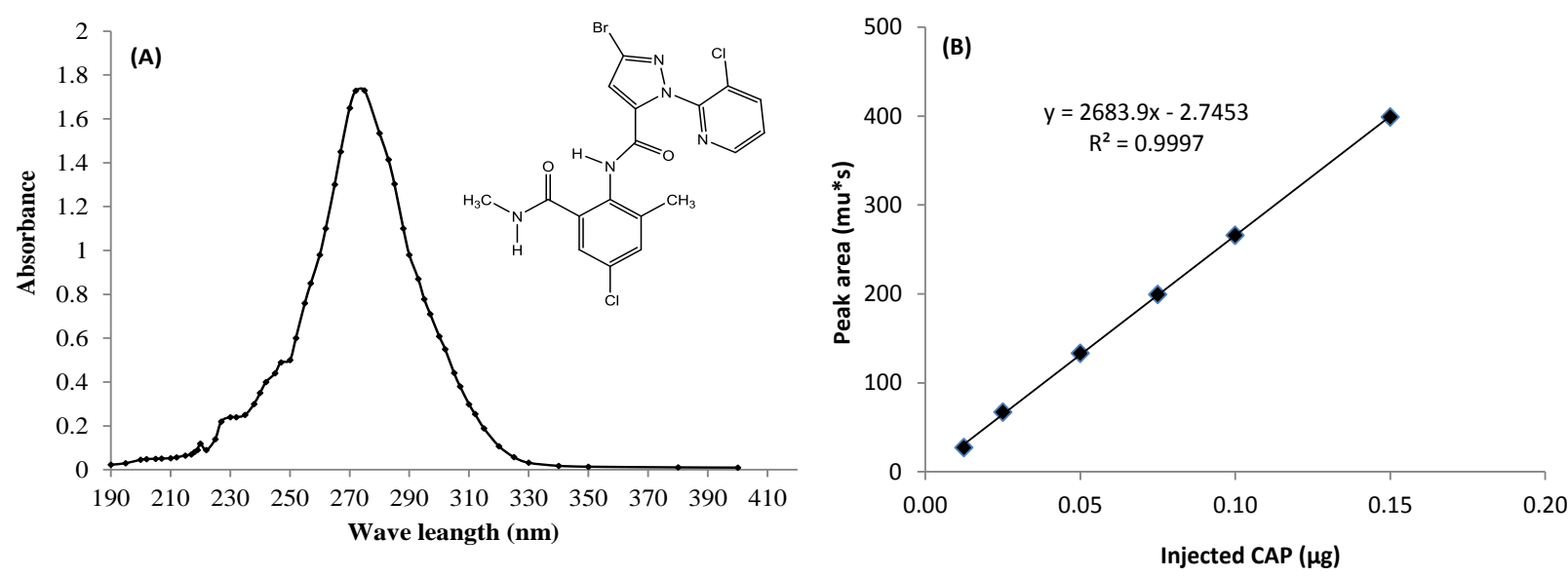

Figure 1. Spectral-Density $(S-D)$ curve of chlorantraniliprole $(A) .190$ to $400 \mathrm{~nm}$ spectra are plotted and clearly show the maximum wavelength is $273 \mathrm{~nm}$ and Calibration-Density $(C-D)$ curve of chlorantraniliprole (B) at $273 \mathrm{~nm}$ using Agilent $1260 \mathrm{HPLC}-\mathrm{VWD}$

\subsubsection{Extraction and Clean Up}

A weight of $10 \mathrm{~g}$ of soil sample was taken at different times of $0,3,7,10,15,30$, and 60 days into 25$\mathrm{mL}$ centrifuge tubes. $20 \mathrm{~mL}$ of solvent mixture of methanol-water (90:10) was added. The tube was closed and stirred vigorously by hand for $1 \mathrm{~min}$. To induce phase separation and pesticides partitioning salt mixture (composed of $0.5 \mathrm{~g}$ of anhydrous magnesium sulfate, $0.1 \mathrm{~g}$ sodium chloride and $0.15 \mathrm{~g}$ of sodium acetate) was added to the slurry from the first extraction. The tube was closed, shaken vigorously by hand for $1 \mathrm{~min}$ and centrifuged for $1 \mathrm{~min}$ at $2000 \mathrm{rpm}$ and then filtered through Whatman filter paper No. 1. The organic layer was transferred to a $10-\mathrm{mL}$ centrifugation tube containing $0.15 \mathrm{~g}$ of Magnesium sulphate and $0.05 \mathrm{~g}$ activated charcoal per $\mathrm{mL}$ extract to remove pigments and undesired co-extractives. The tube was closed, shaken vigorously by hand for $30 \mathrm{~s}$, and centrifuged for $5 \mathrm{~min}$ at $3000 \mathrm{rpm}$ (Anastassiades et al. 2003).

\subsubsection{Determination by HPLC}

The quantification of CAP was determined by an Agilent 1260 HPLC Infinity system (Germany). Five microliter of each sample extract was injected onto the HPLC column using the autosampler apparatus with a $100 \mu \mathrm{L}$ sample loop. Separation was performed on ZORBAX Eclips Plus C18 column $(250 \times 4.6 \mathrm{~mm}$ id, $5 \mu \mathrm{m}$ particle size). The mobile phase composition was methanol and water (90:10) with a flow rate of $1 \mathrm{~mL} / \mathrm{min}$. Column temperature was $40^{\circ} \mathrm{C}$ and the detection wavelength was $273 \mathrm{~nm}$. Data were managed using a HP Chemstation software.

\subsubsection{Recovery Assay}

Untreated soil samples were homogenized before being spiked with standard solutions of CAP $(5,10$, and $50 \mu \mathrm{g} / \mathrm{g}$ soil). The samples were processed according to the above procedure. At each fortification 
level, three replicates were analyzed. Results of the pesticides in dissipation experiments were corrected according to the recovery rate. Blank analyses were performed in order to check interference from the matrix (Estes and Lynch 2003).

\subsection{Dissipation Kinetics and Modeling Studies}

For dissipation kinetics study, the soil samples were collected at different time intervals $(0,3,7,10$, 15, 30 and 60 days) and were analyzed by HPLC method. The calculation for dissipation kinetics of CAP in the soil was done by plotting the residue concentration against time (day). The concentration and half-life of CAP were fitted by the first-order kinetics equations, $C_{t}=C_{0} \mathrm{e}^{(-\mathrm{k} t)}$ and $t_{1 / 2}=0.6932 / \mathrm{k}$, respectively (Chai et al. 2013; Liang et al. 2011). To get a straight line, the logarithmic equation was used, $\ln C_{t}=\ln C_{0}{ }^{-\mathrm{k} t}$, with variables defined as follows: $C_{t}$ is the concentration at time $t, C_{0}$ is the initial concentration, $k$ is the rate constant, and $t_{1 / 2}$ is the half-life.

The Minitab software modeled the experiments and reduced the time and the cost as well as increased the precision. The data were fitted to the second order polynomial equation 1 as follows:

$$
\mathrm{Y}=\mathrm{b}_{0}+\mathrm{b}_{1} \mathrm{X}_{1}+\mathrm{b}_{2} \mathrm{X}_{2}+\mathrm{b}_{3} \mathrm{X}_{3}+\mathrm{b}_{4} \mathrm{X}_{4}+\mathrm{b}_{5} \mathrm{X}_{5}
$$

Where, $\mathrm{Y}$ is the dependent variable (CAP dissipation, $\%$ ); $\mathrm{X}_{1}$ to $\mathrm{X}_{5}$ are the independent variables; $\mathrm{b}_{\mathrm{o}}$ is the regression coefficient at center point; $b_{1}$ to $b_{5}$ are the linear coefficients. The second order polynomial equation was used to find out the relationship between the independent variables and the response. In order to ensure a good model, the quality of the fit of the polynomial model equation was expressed by $r^{2}$, the coefficient of determination. The value of $r^{2}$, which is closer to 1.0, indicates the better fitness of the model in the experimental data. Adding center points to a factorial design allows us to detect curvature in the response surface. The conditions applied in each experiment were modified using different combinations of the two selected levels (Kadiyala and Kumar 2008).

\subsection{Side Effect Dehydrogenase (DHase) Activity}

The DHase activity in soil was determined colorimetrically according to the reduction of 2,3,5triphenyltetrazolium chloride (TTC, colorless) to triphenylformazan (TPF, red color) which is extracted by methanol and measured using ELISA reader at $490 \mathrm{~nm}$ with slightly modified methods (Casida Jr et al. 1964; Tabatabai 1994). At each sampling time, five grams of the treated soil sample were inserted into a test tube (10 mL capacity) and addition of $1 \mathrm{~mL}$ of $1 \%$ aqueous solution of TTC and $2 \mathrm{~mL}$ of distilled water. The tubes were tightly covered with parafilm paper to ensure anaerobic condition and then incubated in the dark at $37^{\circ} \mathrm{C}$ for $24 \mathrm{~h}$. After incubation, the TPF produced was extracted by using four $\mathrm{mL}$ of methanol for each tube and the contents were shaken vigorously, stirred for one minute and filtered through Whatman filter paper No. 1. Extraction was repeated three times and the extracts were combined together. The absorbance of TPF in the filtrate was determined colorimetrically at $490 \mathrm{~nm}$ by ELISA reader. The blank sample without TTC solution was done and its methanol extract was used as a reference blank in this determination. DHase activity was expressed based on the dry weight of soil in micromoles of TPF per gram of soil per $24 \mathrm{~h}$. The standard calibration curve for TPF was made in the range of $200-2000 \mathrm{mg} / \mathrm{L}$ and the $\mathrm{K}$ value was computed to be 0.0005 (Figure 2).

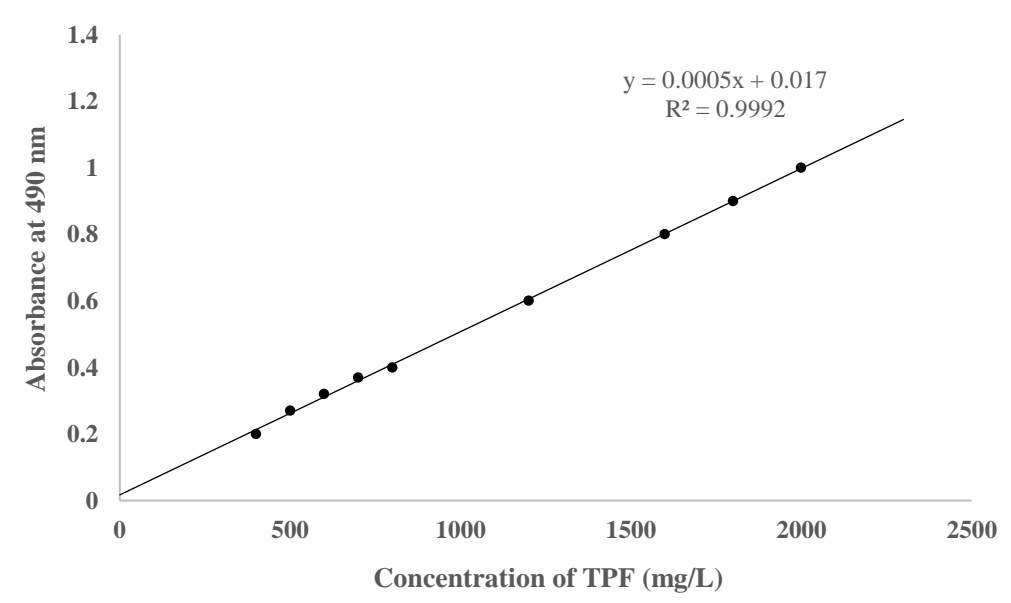

Figure 2. Standard calibration curve of TPF at $490 \mathrm{~nm}$ by Spectrophotometric method 


\subsection{Statistical Analysis}

Experimental data are presented as mean \pm standard error and the statistical analysis was performed by Minitab software. One - way analysis of variance (ANOVA) was used to analyze the data of dissipation and enzymatic activity and means property values were separated $(p \leq 0.05)$ with StudentNewman-Keuls (SNK) test . Minitab software (Minitab® 17.1.0.0. 2006 Inc.) was used to design the experiments and calculation of means and standard errors. Model adequacy checks were carried out by examining various plots (scatter, histograms and normal probability) of the residuals.

\section{RESULTS AND DISCUSSION}

\subsection{HPLC Method Validation}

The development and validation method for determination of CAP was performed on Agilent 1260 HPLC Infinity system (Germany) equipped with an Agilent variable wavelength ultraviolet detector (VWD). The linearity of instrument was determined from plotting the chromatographic calibration curve by injecting standard CAP at concentrations ranging from 0.0125 to $0.15 \mu \mathrm{g}$ into the HPLCVWD. The response of the detector to CAP concentration was linear, $y=2683.9 x-2.7453$ with high correlation coefficient, $r^{2}=0.9997$ (Figure 1B). The retention time of CAP was $4.36 \pm 0.001 \mathrm{~min}$. The limits of detection (LOD) and quantification (LOQ) for CAP using HPLC-VWD were 0.024 and $0.074 \mu \mathrm{g}$, respectively.

Recovery experiments were performed to validate the extraction method and the results of recoveries of CAP in soil A and B are shown in Table 3. The recoveries were performed at levels of 5, 10 and 50 $\mu \mathrm{g} / \mathrm{g}$ soil with extraction by methanol: water in both soil types. The recovery percentages were $115.35,99.45$ and $78.78 \%$ at 5,10 and $50 \mu \mathrm{g} / \mathrm{g}$ soil, respectively for soil A. However, the recovery percentages were $95.29,87.59$ and $60.05 \%$ at 5,10 and $50 \mu \mathrm{g} / \mathrm{g}$ soil, respectively for soil $\mathrm{B}$. The recovery exceed than $100 \%$ in some cases as to the presence of interfering materials extracted with the target pesticides (Malhat et al. 2012). It can be noted that the recovery decreased with an increase of the level of concentration. In addition, soil A indicated higher recoveries than soil B. This may be refers to the high organic matter in soil A compared with the soil B . The results of CAP of our study are in agreements with previous studies, which confirmed that the recovery of CAP was depended on the conditions and soil type. For example, the recovery of CAP in soil sample was found to be ranged from 95 to $102 \%$ at rang of CAP from $0.05-1.00 \mathrm{mg} / \mathrm{kg}$ soil (Malhat et al. 2012; Malhat 2012). Zhang and others studied the recovery of CAP in rice field ecosystem and they reported that the recovery was ranged from 76.90 to $103.10 \%$ at 0.0001 to $0.1 \mathrm{mg} / \mathrm{kg}$ (Zhang et al. 2012). Sharma and co-authors studied the recovery of CAP in sugarcane field soil and they found that the recovery was ranged from 87.29 to $95.80 \%$ at 0.01 to $1.00 \mathrm{mg} / \mathrm{kg}$ (Sharma et al. 2014b). Wang and Zhang studied determination of the dissipation dynamics and residue behaviors of CAP in soil by LC-MS/MS they found that the recovery was ranged from 81.90 to $97.7 \%$ at 0.010 to $4.00 \mathrm{mg} / \mathrm{kg}$ (Wang and Zhang 2017).

Table 3. Recovery percentages of CAP in soil A and B by HPLC

\begin{tabular}{|l|c|c|c|c|}
\hline \multirow{2}{*}{ Soil Type } & \multicolumn{4}{|c|}{ Recovery (\%) \pm SE } \\
\cline { 2 - 5 } & $\mathbf{5} \mathbf{~ u g} / \mathbf{g}$ soil & $\mathbf{1 0} \mathbf{~ u g} / \mathbf{g}$ soil & $\mathbf{5 0} \mathbf{~ u g} / \mathbf{g}$ soil & Mean \pm SE \\
\hline A & $115.35^{\mathrm{a}} \pm 9.51$ & $99.45^{\mathrm{a}} \pm 6.10$ & $78.78^{\mathrm{a}} \pm 4.70$ & $97.86 \pm 6.77$ \\
\hline B & $95.29^{\mathrm{b}} \pm 0.14$ & $87.59^{\mathrm{c}} \pm 3.41$ & $60.05^{\mathrm{c}} \pm 0.59$ & $79.64 \pm 1.38$ \\
\hline
\end{tabular}

Values are mean of three replicates and given as mean \pm standard error. Different letters $(a-d)$ in columns indicate the range from higher to lower rank as significant differences according to the SNK test $(P \leq 0.05)$.

\subsection{Dissipation of CAP in Soil A and B}

The dissipated residues of CAP were calculated by first-order exponential decay model $\left(C_{t}=C_{0} \mathrm{e}^{(-\mathrm{k} t)}\right)$. The effectiveness of the soil type and selected factors in measuring trace levels of CAP was monitored and studied under laboratory conditions. The residues of CAP $(\mu \mathrm{g} / \mathrm{g})$ in different soil treatments at different time intervals during the storage at 25 and $50^{\circ} \mathrm{C}$ are shown in Figure 3 . The insecticide residues were detected in all samples up to 30 days of storage with decline in their concentrations with the time of storage. However, the residues reached below the quantification limit $(\mathrm{LOD}=0.024 \mu \mathrm{g})$ at day 60 after treatment irrespective of the dose applied. The residues of CAP in treatment $\mathrm{T}_{1}$ soil $\mathrm{A}$, wheat straw, non-sterilization and at $50^{\circ} \mathrm{C}$ rapidly decreased during the 
experiment (from $56.64 \mu \mathrm{g} / \mathrm{g}$ soil at zero time to $6.35 \mu \mathrm{g} / \mathrm{g}$ soil at day 30 ). However, the $\mathrm{T}_{11}$ treatment of soil B that include wheat straw, non-sterilization and incubation at $25^{\circ} \mathrm{C}$ showed slightly decrease of the insecticide concentration during the storage period (from $53.03 \mu \mathrm{g} / \mathrm{g}$ soil at zero time to 7.31 $\mu \mathrm{g} / \mathrm{g}$ soil at day 30$)$.
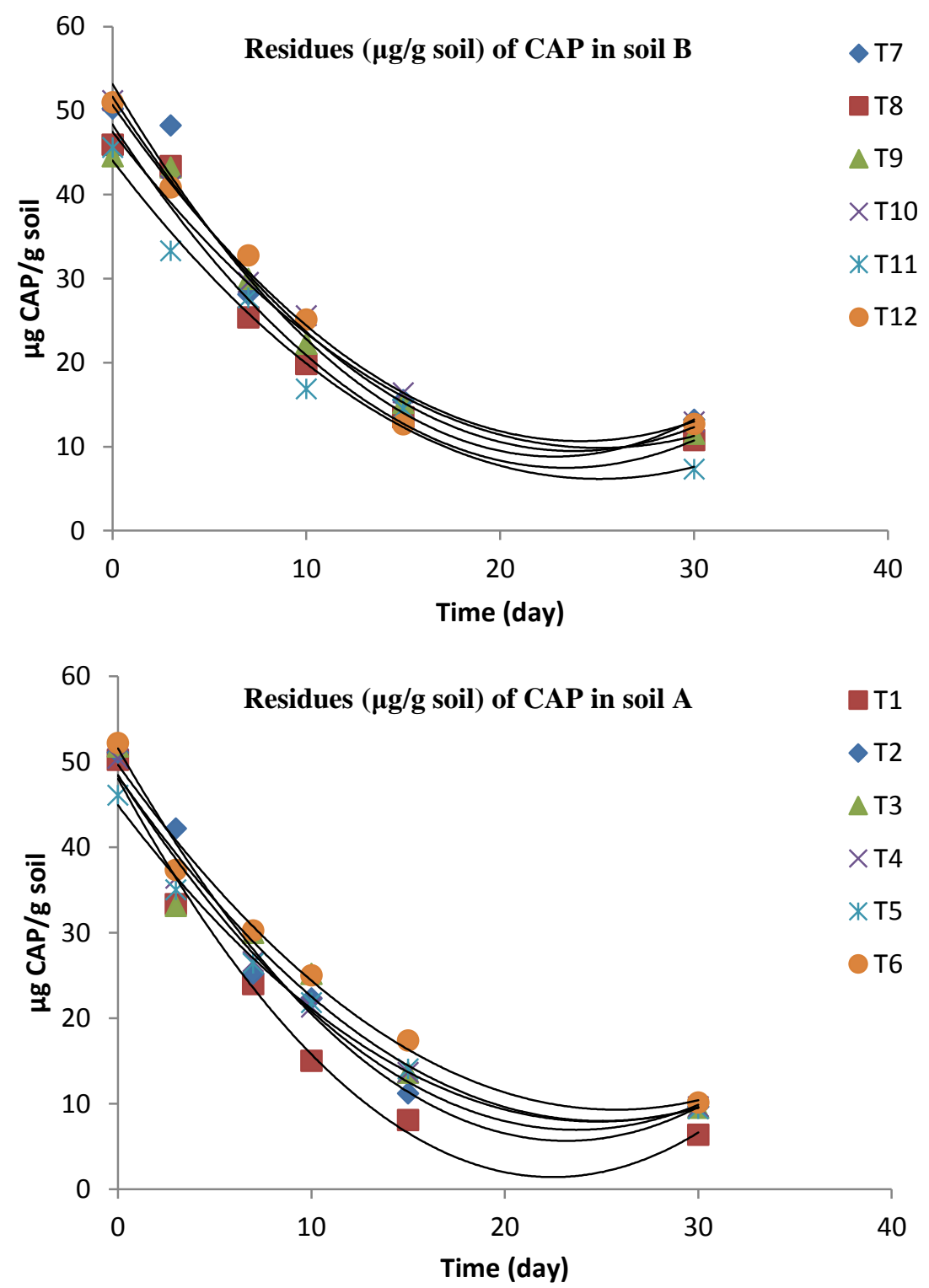

Figure 3. Dissipation curves of CAP in soil A and B with or without wheat straw at deferent conditions. The lines fitted to the experimental data describe CAP dissipation according to the first-order kinetics

The average levels of CAP residues found approximately 30 days after treatment were 6.35 and 13.19 $\mu \mathrm{g} / \mathrm{g}$ soil in soil A and B, respectively. It can be noted that the soil A showed higher CAP dissipation than the soil B. This may be refers to the soil A was rich in organic matter than soil B (Pal et al. 2010).

The dissipation rates of CAP residues in soil A and B at different time intervals by HPLC are presented in Tables 4 and 5 respectively. Generally, CAP dissipated rapidly after application with all soil treatments in both of soil A and B. The percentage of CAP dissipation after three days of treatment was ranged from 25.55 to $38.19 \%$ in soil A and from 9.09 to $37.18 \%$ in soil B. However, the percentage of dissipation after 30 days of treatment was ranged from 82.10 to $88.79 \%$ in soil A and from 75.14 to $86.22 \%$ in soil B.

It can be noted that the soil A that contain wheat straw, incubated at $50^{\circ} \mathrm{C}$ and non-sterilized $\left(\mathrm{T}_{1}\right)$ and soil of wheat straw, incubated $25^{\circ} \mathrm{C}$ and with sterilization $\left(\mathrm{T}_{2}\right)$ led to dissipation of the CAP rapidly than the other treatments ( 88.79 and $83.01 \%$ at day 30 , receptively ). However, the soil without wheat 
Effect of Different Soil Treatments on Dissipation of Chlorantraniliprole and Dehydrogenase Activity Using Experimental Modeling Design

straw, incubated at $25^{\circ} \mathrm{C}$ and non-sterilized $\left(\mathrm{T}_{5}\right)$ and that without wheat straw, incubated at $25^{\circ} \mathrm{C}$ and sterilized $\left(\mathrm{T}_{6}\right)$ did not dissipate CAP rapidly. In addition, it can be noted that the soil $\mathrm{B}$ that contain wheat straw, incubated $25^{\circ} \mathrm{C}$ and non-sterilized $\left(\mathrm{T}_{11}\right)$ and that contain wheat straw, incubated at $50^{\circ} \mathrm{C}$ and non-sterilized $\left(\mathrm{T}_{8}\right)$ led to dissipate the CAP rapidly than the other treatments $(79.71$ and $86.22 \%$ at day 30, respectively). However, soil with wheat straw, incubated at $25^{\circ} \mathrm{C}$ and sterilized $\left(\mathrm{T}_{7}\right)$ and that without wheat straw, incubated at $25^{\circ} \mathrm{C}$ and sterilized $\left(\mathrm{T}_{10}\right)$ did not dissipate CAP rapidly (3.47$75.58 \%$ dissipation during 30 days of incubation).

Table 4. Dissipation percentages of CAP in soil A at different time intervals by HPLC

\begin{tabular}{|l|c|c|c|c|c|c|c|}
\hline \multirow{2}{*}{ Treatment } & \multicolumn{7}{|c|}{ Dissipation (\%) at time (day) } \\
\cline { 2 - 8 } & $\mathbf{0}$ & $\mathbf{3}$ & $\mathbf{7}$ & $\mathbf{1 0}$ & $\mathbf{1 5}$ & $\mathbf{3 0}$ & $\mathbf{6 0}$ \\
\hline $\mathrm{T}_{1}$ & $11.33^{\mathrm{b}} \pm 3.90$ & $41.16^{\mathrm{a}} \pm 1.47$ & $57.68^{\mathrm{a}} \pm 2.14$ & $73.50^{\mathrm{a}} \pm 0.66$ & $85.73^{\mathrm{a}} \pm 0.42$ & $88.79^{\mathrm{a}} \pm 0.75$ & $\mathrm{ND}$ \\
\hline $\mathrm{T}_{2}$ & $9.80^{\mathrm{d}} \pm 1.30$ & $25.55^{\mathrm{e}} \pm 0.03$ & $55.47^{\mathrm{b}} \pm 1.74$ & $60.62^{\mathrm{d}} \pm 0.05$ & $80.25^{\mathrm{b}} \pm 0.06$ & $83.01^{\mathrm{c}} \pm 0.88$ & $\mathrm{ND}$ \\
\hline $\mathrm{T}_{3}$ & $8.61^{\mathrm{e}} \pm 1.56$ & $41.53^{\mathrm{a}} \pm 0.01$ & $47.12^{\mathrm{e}} \pm 2.11$ & $55.56^{\mathrm{e}} \pm 0.03$ & $75.95^{\mathrm{c}} \pm 0.17$ & $83.22^{\mathrm{b}} \pm 0.83$ & $\mathrm{ND}$ \\
\hline $\mathrm{T}_{4}$ & $11.06^{\mathrm{c}} \pm 2.47$ & $35.82^{\mathrm{c}} \pm 0.02$ & $53.06^{\mathrm{d}} \pm 3.91$ & $62.45^{\mathrm{b}} \pm 0.06$ & $75.85^{\mathrm{c}} \pm 0.04$ & $83.01^{\mathrm{c}} \pm 1.03$ & $\mathrm{ND}$ \\
\hline $\mathrm{T}_{5}$ & $18.64^{\mathrm{a}} \pm 2.46$ & $38.19^{\mathrm{b}} \pm 0.04$ & $53.36^{\mathrm{c}} \pm 0.03$ & $61.48^{\mathrm{c}} \pm 0.02$ & $75.19^{\mathrm{d}} \pm 1.71$ & $83.38^{\mathrm{b}} \pm 0.98$ & $\mathrm{ND}$ \\
\hline $\mathrm{T}_{6}$ & $7.86^{\mathrm{f}} \pm 5.56$ & $34.08^{\mathrm{d}} \pm 2.28$ & $46.59^{\mathrm{f}} \pm 1.31$ & $55.63^{\mathrm{e}} \pm 0.01$ & $69.32^{\mathrm{e}} \pm 0.00$ & $82.10^{\mathrm{d}} \pm 1.27$ & $\mathrm{ND}$ \\
\hline
\end{tabular}

Values are mean of three replicates and given as mean \pm standard error. Different letters (a-e) in columns indicate the range from higher to lower rank as significant differences according to the SNK test $(P \leq 0.05)$.

Table 5. Dissipation percentages of CAP in soil B at different time intervals by HPLC

\begin{tabular}{|l|c|c|c|c|c|c|c|}
\hline \multirow{2}{*}{ Treatment } & \multicolumn{7}{|c|}{ Dissipation (\%) at time (day) } \\
\cline { 2 - 8 } & $\mathbf{0}$ & $\mathbf{3}$ & $\mathbf{7}$ & $\mathbf{1 0}$ & $\mathbf{1 5}$ & $\mathbf{3 0}$ & $\mathbf{6 0}$ \\
\hline $\mathrm{T}_{7}$ & $5.25^{\mathrm{d}} \pm 2.87$ & $9.09^{\mathrm{f}} \pm 0.58$ & $46.93^{\mathrm{c}} \pm 1.32$ & $61.73^{\mathrm{c}} \pm 0.05$ & $70.72^{\mathrm{e}} \pm 2.76$ & $75.14^{\mathrm{f}} \pm 1.00$ & $\mathrm{ND}$ \\
\hline $\mathrm{T}_{8}$ & $13.36^{\mathrm{c}} \pm 2.69$ & $18.17^{\mathrm{e}} \pm 2.75$ & $52.14^{\mathrm{a}} \pm 0.04$ & $62.64^{\mathrm{b}} \pm 0.07$ & $74.59^{\mathrm{b}} \pm 1.00$ & $79.71^{\mathrm{b}} \pm 0.32$ & $\mathrm{ND}$ \\
\hline $\mathrm{T}_{9}$ & $15.99^{\mathrm{a}} \pm 2.11$ & $18.52^{\mathrm{d}} \pm 1.62$ & $43.49^{\mathrm{e}} \pm 0.03$ & $58.08^{\mathrm{d}} \pm 0.03$ & $71.31^{\mathrm{d}} \pm 2.07$ & $78.26^{\mathrm{c}} \pm 0.23$ & $\mathrm{ND}$ \\
\hline $\mathrm{T}_{10}$ & $3.47^{\mathrm{f}} \pm 3.55$ & $22.57^{\mathrm{b}} \pm 4.86$ & $44.29^{\mathrm{d}} \pm 2.98$ & $51.78^{\mathrm{f}} \pm 2.98$ & $69.02^{\mathrm{f}} \pm 7.12$ & $75.58^{\mathrm{e}} \pm 0.48$ & $\mathrm{ND}$ \\
\hline $\mathrm{T}_{11}$ & $14.00^{\mathrm{b}} \pm 3.36$ & $37.18^{\mathrm{a}} \pm 0.51$ & $47.72^{\mathrm{b}} \pm 0.03$ & $68.20^{\mathrm{a}} \pm 0.06$ & $72.64^{\mathrm{c}} \pm 3.22$ & $86.22^{\mathrm{a}} \pm 0.03$ & $\mathrm{ND}$ \\
\hline $\mathrm{T}_{12}$ & $3.84^{\mathrm{e}} \pm 7.86$ & $22.00^{\mathrm{c}} \pm 7.54$ & $38.24^{\mathrm{f}} \pm 5.14$ & $52.64^{\mathrm{e}} \pm 3.90$ & $76.14^{\mathrm{a}} \pm 0.20$ & $76.04^{\mathrm{d}} \pm 0.04$ & $\mathrm{ND}$ \\
\hline
\end{tabular}

Values are mean of three replicates and given as mean \pm standard error. Different letters (a-f) in columns indicate the range from higher to lower rank as significant differences according to the SNK test $(P \leq 0.05)$.

The dissipation was described mathematically by a first order equation. The results of Equation order (n); constant $(\mathrm{K})$ and half-life $\left(\mathrm{t}_{0.5}\right)$ of CAP in soil A and B are shown in Table 6 . The equation order (n) found to be one as obtained throatily and curve. The constant $\mathrm{K}$ for dissipation in soil A ranged from 0.067 to 0.103 for calculated and form 0.060 to 0.092 for that obtained values from curve. $\mathrm{T}_{1}$ showed the highest $\mathrm{K}$ value $(0.103)$ however, $\mathrm{T}_{5}$ and $\mathrm{T}_{6}$ showed the lowest values $(0.068$ and 0.067 , receptively). The treatments $\mathrm{T}_{2}, \mathrm{~T}_{3}$ and $\mathrm{T}_{4}$ were moderately in $\mathrm{K}$ value (ranged from 0.075 to 0.076 ). The data of $t_{0.5}$ calculated from equation $\left(t_{0.5}=0.6932 / K\right)$ showed that $T_{5}$ and $T_{6}$ were the highest value (10.37 and 10.30 days respectively). However, $\mathrm{T}_{1}$ was the lowest $\left(\mathrm{t}_{0.5}=6.72\right.$ days). Treatments of $\mathrm{T}_{2}, \mathrm{~T}_{3}$ and $\mathrm{T}_{4}$ showed moderate values of $\mathrm{t}_{0.5}$ (9.08, 9.14 and 9.28 days, respectively). It can be noted that the soil A that contain wheat straw, incubated at $50^{\circ} \mathrm{C}$ and non-sterilized led to dissipation the CAP rapidly than the other treatments. However, soil without wheat straw, incubated at $25^{\circ} \mathrm{C}$ and non-sterilized $\left(\mathrm{T}_{5}\right)$ and that without wheat straw, incubated at $25^{\circ} \mathrm{C}$ and sterilized $\left(\mathrm{T}_{6}\right)$ did not dissipate CAP rapidly.

For soil B, the equation order (n) found to be one as obtained throatily and curve. The constant $\mathrm{K}$ ranged from 0.059 to 0.078 for calculated and form 0.060 to 0.092 for that obtained values from curve. $\mathrm{T}_{11}$ and $\mathrm{T}_{12}$ showed the highest $\mathrm{K}$ value $(0.078-0.071)$ however, $\mathrm{T}_{9}$ showed the lowest value (0.059). The treatments $T_{7}, T_{8}$ and $T_{10}$ were moderately in $K$ value (ranged from 0.062 to 0.066 ). The data of $\mathrm{t}_{0.5}$ calculated from equation $\left(\mathrm{t}_{0.5}=0.6932 / \mathrm{K}\right)$ showed that $\mathrm{T}_{9}$ and $\mathrm{T}_{10}$ were the highest value (11.72 and 11.24 day respectively). However $T_{11}$ was the lowest $\left(t_{0.5}=8.83\right.$ days). Treatments of $T_{7}$, $\mathrm{T}_{8}$ and $\mathrm{T}_{12}$ showed moderate values of $\mathrm{t}_{0.5}(10.76,10.57$ and 9.77 days, respectively). It can be noted that the soil B that contain wheat straw, incubated at $50^{\circ} \mathrm{C}$ and non-sterilized led to dissipation the $\mathrm{CAP}$ rapidly than the other treatments. However, soil B without wheat straw, incubated at $25^{\circ} \mathrm{C}$ and non-sterilized $\left(\mathrm{T}_{9}\right)$ and that without wheat straw, incubated at $50^{\circ} \mathrm{C}$ and sterilized $\left(\mathrm{T}_{10}\right)$ did not dissipate CAP rapidly. 
Effect of Different Soil Treatments on Dissipation of Chlorantraniliprole and Dehydrogenase Activity Using Experimental Modeling Design

Table 6. Dissipation rate constant $(K)$ and half-life $\left(t_{0.5}\right)$ of $C A P$ in soil $A$ and $B$ without and with wheat straw at different conditions

\begin{tabular}{|l|l|l|l|l|l|}
\hline \multirow{2}{*}{ Soil type } & \multirow{2}{*}{ Treatment } & \multicolumn{2}{|c|}{ K } & \multicolumn{2}{c|}{$\mathbf{t}_{\mathbf{0 . 5}}$} \\
\cline { 2 - 6 } & & Mathematically & Graphically & Mathematically & Graphically \\
\hline \multirow{5}{*}{ Soil A } & $\mathrm{T}_{1}$ & 0.103 & 0.092 & 6.72 & 7.52 \\
\cline { 2 - 6 } & $\mathrm{T}_{2}$ & 0.076 & 0.085 & 9.08 & 8.15 \\
\cline { 2 - 6 } & $\mathrm{T}_{3}$ & 0.076 & 0.064 & 9.14 & 10.83 \\
\cline { 2 - 6 } & $\mathrm{T}_{4}$ & 0.075 & 0.073 & 9.28 & 9.49 \\
\cline { 2 - 6 } & $\mathrm{T}_{5}$ & 0.068 & 0.060 & 10.37 & 11.55 \\
\cline { 2 - 6 } & $\mathrm{T}_{6}$ & 0.067 & 0.061 & 10.30 & 11.40 \\
\hline \multirow{5}{*}{ Soil B } & $\mathrm{T}_{7}$ & 0.064 & 0.092 & 10.76 & 9.92 \\
\cline { 2 - 6 } & $\mathrm{T}_{8}$ & 0.066 & 0.075 & 10.57 & 9.48 \\
\cline { 2 - 6 } & $\mathrm{T}_{9}$ & 0.059 & 0.060 & 11.72 & 11.63 \\
\cline { 2 - 6 } & $\mathrm{T}_{10}$ & 0.062 & 0.069 & 11.24 & 10.10 \\
\cline { 2 - 6 } & $\mathrm{T}_{11}$ & 0.078 & 0.060 & 8.83 & 9.01 \\
\cline { 2 - 6 } & $\mathrm{T}_{12}$ & 0.071 & 0.074 & 9.77 & 9.31 \\
\hline
\end{tabular}

$K$ was calculated from $K=\left[2.303 / t_{2}-t_{1}\right] \log \left[C_{l} / C_{2}\right] . t_{0.5}$ was calculated from $t_{0.5}=(0.6932 / K)$

Generally, the dissipation of the pesticide residues in soil depending on the environmental conditions, type of application, dosage, temperature, $\mathrm{pH}$, and interval between applications (Khay et al. 2008; Scholz-Starke et al. 2017). The factor of soil type in the present study confirmed that the soil A (Alluvial) showed higher dissipation than soil B (Calcareous). The result is consistent with previous studies that have shown that soil clay loam including pesticides has a high dissipation compared to clayey clay soil. Mariusz Cycon studied the ability of Serratia marcescens degrading diazinon to eliminate chlorpyrifos (CP), fenitrothion (FT) and parathion (PT) in mineral salt medium (MSM) and in three soils of different characteristics (Mariusz et al. 2013). This strain was able to use all insecticides at a concentration of $50 \mathrm{mg} / \mathrm{L}$ as the sole source of carbon when cultured in MSM, and 58.90, 70.50 and $82.50 \%$ of initial dose of CP, FT and PT, respectively, were degraded within 14 days. During the 42-day experiment, 45.30, 61.40 and $72.50 \%$ of the initial dose of CP, FT and PT, respectively, were eliminated in the sandy soil whereas CP degradation, FT and PT in the same period, sandy soils and silty soils reached $61.4,79.7$ and $64.2 \%$ and $68.9,81.0$ and $63.6 \%$, respectively. Inoculation of non-sterile soils with $S$. marcescens improved the disappearance rates of all insecticides and $\mathrm{t}_{0.5}$ for CP, FT and PT was reduced by 20.7, 11.3 and 13.0 days, and 11, 9, 7.0 and 8.1 days and 9.7, 14.5 and 12.6 days in sandy and loamy soils, respectively, relative to non-sterile soils with only one native microflora (Mariusz et al. 2013).

The factor of temperature in the present study confirmed that the soil that incubated at high temperature $\left(50^{\circ} \mathrm{C}\right)$ showed higher dissipation that incubated at $25^{\circ} \mathrm{C}$. This result is in agreement with other previous studies which proved that the soil including pesticides showed high dissipation when it incubated at high temperature compared to that incubated at low temperature (Nadelhoffer et al. 1991; Singh et al. 1985). In addition, the effect of sterilization of the dissipation of pesticide in soil was also investigated. The current study confirmed that the soil treatments that non-sterilized showed higher dissipation than serialized soil. This finding is in agreement with previous studies which found that the non-sterilized soil had high dissipation of CAP compared to the sterilized soil (Fletcher and Kaufman 1980; Sharma et al. 2014a).

The factor of soil amendment in the present study confirmed that the soil-wheat straw showed higher dissipation that soil of non-wheat straw. This finding is in agreement with Fogg and others who reported that the presence of wheat straw in soil enhanced the degradation of CAP (Fogg et al. 2003). Satyanarayan and Murkute reported that the presence of wheat straw in soil enhanced also the degradation of CAP (Satyanarayan and Murkute 2008). Wang and Zhang studied the determination of the dissipation dynamics and residue behaviors of CAP in sugarcane and soil by LC-MS/MS and they reported that the dissipation pattern and final residue behavior of CAP in sugarcane under field conditions were also investigated based on the established method. The half-life of CAP in soil were from 8.89 to 12.38 days at both locations. The residues of CAP in sugarcane plant reached the maximum values in 5-7 days. The final residue concentrations of CAP were $<0.05 \mathrm{mg} / \mathrm{kg}$ (MRL set by China) in sugarcane samples, which meant that sugarcane samples collected at harvest were safe under the recommended application method of $0.03 \%$ CAP granule (insecticide-fertilizer) (Wang and Zhang 2017). Scholz-Starke and others studied the dissipation of CAP, chlorpyrifos-methyl and 
indoxacarb insecticides and found that the half-life of insecticides tested varied from 4 to 6 days for chlorpyrifos-methyl at 16-17 days for chlorantraniliprole and 20-24 days for indoxacarb. The insecticides tested achieved levels below the MRL of $0.05 \mathrm{mg} / \mathrm{kg}$ much faster than their PHIs (ScholzStarke et al. 2017).

Our results are in agreements with Dong et al. who studied the determination of CAP residues in corn and soil by UPLC-ESI-MS/MS and they found that the half-life of CAP ranged from 12.6 to 23.1 days in soils and ranged from 4.9 to 5.4 days in corn (Dong et al. 2011). Zhang and other calculated the half-life of CAP in soil of rice field ecosystem to be 16.0 days (Zhang et al. 2012). Malhat et al studied the results showed half-life value of 3.30 and 3.66 days for CAP in tomato fruit and soil (Malhat et al. 2012) and the dissipated in tomato fruit and soil followed the first order kinetics (Malhat et al. 2012; Sharma et al. 2014b). Vijayasree et al and Ramasubramanian et al reported that CAP dissipated rapidly in cowpea fruits, with a half-life of 1.31 day and persisted in soils of sugarcane with longer half-life of 6.5-6.8 days (Ramasubramanian et al. 2012; Vijayasree et al. 2013). Sharma et al studied the persistence of CAP granule formulation in sugarcane field soil and they reported that the half-life of CAP changed from 8.36 to 8.25 days (Sharma et al. 2014b).

Malhat found that CAP dissipation in grape was 38.95, 61.29, 82.70, 93.67 and 98.09\%, at 1, 3, 7, 10 and 15 days respectively (Malhat 2012). Sharma et al studied the CAP dissipation in sugarcane field soil and they found that the percentage was ranged from 27.67 to $100 \%$ for 56 days (Sharom and Stephenson 1976).

\subsection{Modeling Study of CAP in Soil A and B}

Results clearly indicated that the CAP dissipation efficiency was strongly affected by the variables selected for this study (soil type, soil amendment, temperature, sterilization and incubated time). This was also reflected by the wide range of values for coefficients of the terms of the obtained models (Table 7). The result of the models obtained from Minitab software using create factorial design for CAP in soil A and B at different time intervals are shown in Table 7. Fifteen models were generated with high correlation coefficient $\left(r^{2}\right.$ from 0.72-0.99) and low $s$ value (2.14-7.09). The highest fit model for prediction of the dissipation study was model $5\left(r^{2}=0.99\right.$ and $\left.s=3.05\right)$.

The standardized effects of the independent variables and their interactions on the dependent variable (dissipation of pesticide in the soil) were investigated by preparing a Pareto chart (Figure 4). A Pareto graphic is used to draw conclusions about which of these variables are most significant. The MINITAB statistical analysis program uses Lenth's method (Burr 1990; Reh 2005) in the case of factorial designs without replicates, and from this the Pareto graphic is obtained. This graphic shows both the magnitude and the importance of the effects (variables). It displays the absolute value of the effects in the ordinate and the pseudo-error standard of the effects in the abscissa. The study is done for a $95 \%$ confidence interval. On the Pareto chart there is a reference line (the discontinuous vertical plot), and any effect that extends past this line is potentially important. The reference line corresponds to a simultaneous margin of error. The variables and interactions which can be considered as especially important for the treatments are the incubated time, soil type and sterilization have high effect on dissipation and were statistically significant.

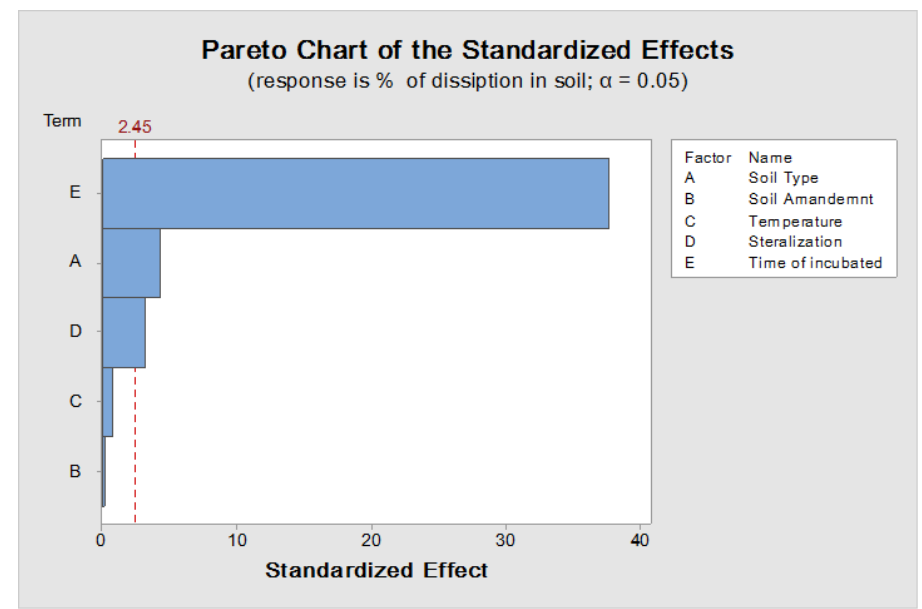

Figure 4. Pareto chart of the standardized effects of CAP in soil A and B with or without wheat straw at deferent condition 
Effect of Different Soil Treatments on Dissipation of Chlorantraniliprole and Dehydrogenase Activity Using Experimental Modeling Design

Table 7. Proposed models obtained from Minitab software using create factorial design for CAP in soil A and B at different time intervals

\begin{tabular}{|c|c|c|c|c|}
\hline Number & $\begin{array}{l}\text { Time } \\
\text { selected } \\
\text { (day) }\end{array}$ & Models CAP of dissipation in soil A and B. & $\mathbf{S}$ & $r^{2}$ \\
\hline 1 & 0 and 3 & $\begin{array}{l}\text { Dissipation }(\%)=9.87-8.83 \text { Soil Type }+0.81 \text { Soil Amendment } \\
+1.26 \text { Temperature- } 3.38 \text { Sterilization }+5.83 \text { Time of incubation }\end{array}$ & 7.09 & 0.85 \\
\hline 2 & 0 and 7 & $\begin{array}{l}\text { Dissipation }(\%)=9.86-3.62 \text { Soil Type }+0.83 \text { Soil Amendment }- \\
0.35 \text { Temperature- } 3.27 \text { Sterilization }+5.630 \text { Time of incubation }\end{array}$ & 4.57 & 0.97 \\
\hline 3 & 0 and 10 & $\begin{array}{l}\text { Dissipation }(\%)=9.46-3.73 \text { Soil Type }+2.03 \text { Soil Amendment }- \\
0.67 \text { Temperature }-4.02 \text { Sterilization }+5.244 \text { Time of incubation }\end{array}$ & 5.27 & 0.98 \\
\hline 4 & 0 and 15 & $\begin{array}{l}\text { Dissipation }(\%)=42.37-4.38 \text { Soil Type }+1.23 \text { Soil Amendment } \\
+0.07 \text { Temperature }-3.78 \text { Sterilization }+32.65 \text { Time of incubation }\end{array}$ & 4.26 & 0.99 \\
\hline 5 & 0 and 30 & $\begin{array}{c}\text { Dissipation }(\%)=10.09-4.30 \text { Soil Type }+0.13 \text { Soil Amendment }- \\
0.656 \text { Temperature }-2.972 \text { Sterilization }+2.3717 \text { Time of incubation }\end{array}$ & 3.05 & 0.99 \\
\hline 6 & 3 and 7 & $\begin{array}{l}\text { Dissipation }(\%)=16.44-3.24 \text { Soil Type }-0.02 \text { Soil Amendment } \\
+0.03 \text { Temperature }-3.34 \text { Sterilization }+4.648 \text { Time of incubation }\end{array}$ & 6.20 & 0.84 \\
\hline 7 & 3 and 10 & $\begin{array}{l}\text { Dissipation }(\%)=16.44-3.36 \text { Soil Type }+1.17 \text { Soil Amendment }- \\
0.29 \text { Temperature }-4.08 \text { Sterilization }+4.518 \text { Time of incubation }\end{array}$ & 6.95 & 0.91 \\
\hline 8 & 3 and 15 & $\begin{array}{l}\text { Dissipation }(\%)=19.14-4.01 \text { Soil Type }+0.38 \text { Soil Amendment } \\
+0.45 \text { Temperature }-3.84 \text { Sterilization }+3.706 \text { Time of incubation }\end{array}$ & 6.01 & 0.96 \\
\hline 9 & 3 and 30 & $\begin{array}{l}\text { Dissipation }(\%)=25.03-3.92 \text { Soil Type }-0.73 \text { Soil Amendment }- \\
0.28 \text { Temperature }-3.03 \text { Sterilization }+1.864 \text { Time of incubation }\end{array}$ & 5.11 & 0.98 \\
\hline 10 & 7 and 10 & $\begin{array}{l}\text { Dissipation }(\%)=15.1-4.30 \text { Soil Type }+2.31 \text { Soil Amendment }- \\
0.41 \text { Temperature }-2.07 \text { Sterilization }+4.69 \text { Time of incubation }\end{array}$ & 6.56 & 0.72 \\
\hline 11 & 7 and 15 & $\begin{array}{l}\text { Dissipation }(\%)=24.62-4.95 \text { Soil Type }+1.52 \text { Soil Amendment } \\
+0.33 \text { Temperature }-1.83 \text { Sterilization }+3.366 \text { Time of incubation }\end{array}$ & 5.29 & 0.93 \\
\hline 12 & 7 and 30 & $\begin{array}{l}\text { Dissipation }(\%)=38.57-4.86 \text { Soil Type }+0.41 \text { Soil Amendment }- \\
0.39 \text { Temperature }-1.02 \text { Sterilization }+1.4255 \text { Time of incubation }\end{array}$ & 3.69 & 0.98 \\
\hline 13 & $\begin{array}{l}10 \text { and } \\
15\end{array}$ & $\begin{array}{l}\text { Dissipation }(\%)=26.20-3.90 \text { Soil Type }+1.91 \text { Soil Amendment } \\
+0.12 \text { Temperature }-3.23 \text { Sterilization }+3.269 \text { Time of incubation }\end{array}$ & 5.61 & 0.82 \\
\hline 14 & $\begin{array}{l}10 \text { and } \\
30\end{array}$ & $\begin{array}{l}\text { Dissipation }(\%)=48.16-3.82 \text { Soil Type }+0.80 \text { Soil Amendment }- \\
0.60 \text { Temperature }-2.42 \text { Sterilization }+1.110 \text { Time of incubation }\end{array}$ & 4.97 & 0.91 \\
\hline 15 & $\begin{array}{l}15 \text { and } \\
30\end{array}$ & $\begin{array}{l}\text { Dissipation }(\%)=66.98-3.964 \text { Soil Type }+1.518 \text { Soil Amendment } \\
+0.763 \text { Temperature }-1.751 \text { Sterilization }+0.4910 \text { Time of incubation }\end{array}$ & 2.14 & 0.91 \\
\hline
\end{tabular}

The length of each bar in the chart indicates the standardized effects of the factor on the response (Solanki et al. 2007). The fact that the bar for C (temperature) and B (soil amendment) factors remained inside the reference line $(2.45$ at $\alpha=0.05)$ in Figure 4, and the smaller coefficients for these terms compared to other terms in Equation (5), indicated that these terms contributed the least in prediction of the dissipation (\%) efficiency. The negative coefficients for the model 5 components (soil type, time of incubated and sterilization) indicated an unfavorable or antagonistic effect on the CAP dissipation efficiency, while the positive coefficients for the model components (soil amendment and time of incubation) showed a favorable or synergistic effect on the CAP dissipation efficiency.

Adinarayana and Ellaiah have reported that three-dimensional (3D) response surface plots as a function of two factors, maintaining all other factors at fixed levels (Adinarayana and Ellaiah 2002). These plots are more helpful in understanding both the main and the interaction effects of the two factors. In addition, 3D response surfaces and their corresponding contour plots can facilitate the straightforward examination of the effects of the experimental variables on the responses (Myers et al. 2016; $\mathrm{Wu}$ et al. 2009). Therefore, in order to gain a better understanding of the effects of the independent variables (soil type, sterilization and time of incubated) and their interactions on the dependent variable (dissipation \% in soil), 3D response surface plots for the measured responses were formed based on the model equation (Equation 5) in this study and were presented in Figure 5 (A-C). The relationship between the dependent and independent variables was further elucidated by constructing contour plots (Figure 5, D-F). Since the regression model has three independent variables, one variable was held at constant at the center level (for the coded form: $x_{i}=0$ or for the uncoded form: $X_{i}=X_{0}$ ) for each plot, therefore, a total of three response 3D plots and three corresponding contour plots were produced for responses. The nonlinear nature of all 3D response 
Effect of Different Soil Treatments on Dissipation of Chlorantraniliprole and Dehydrogenase Activity Using Experimental Modeling Design

surfaces and the respective contour plots demonstrated that there were considerable interactions between each of the independent variables and the CAP dissipation efficiency. Furthermore, it can also be concluded that all the contour plots for a high value of CAP dissipation $(\geq 80 \%)$ were found to be linear. This signified that there was no direct linear relationship among the selected independent variables.

The results of dissipation (\%) of CAP using model 5 versus observed dissipation values in soil A and $\mathrm{B}$ at different time intervals are shown in Table 8. The dissipation (\%) at $0,3,7,10,15$ and 30 days using HPLC and calculated by the model showed that good fitness at $0,3,15$ and 30 days. However, there is a little variation between practically and calculated values at 7 and 10 days. The CAP residues at day-60 in all soil A and B treatments was not detectable by HPLC.

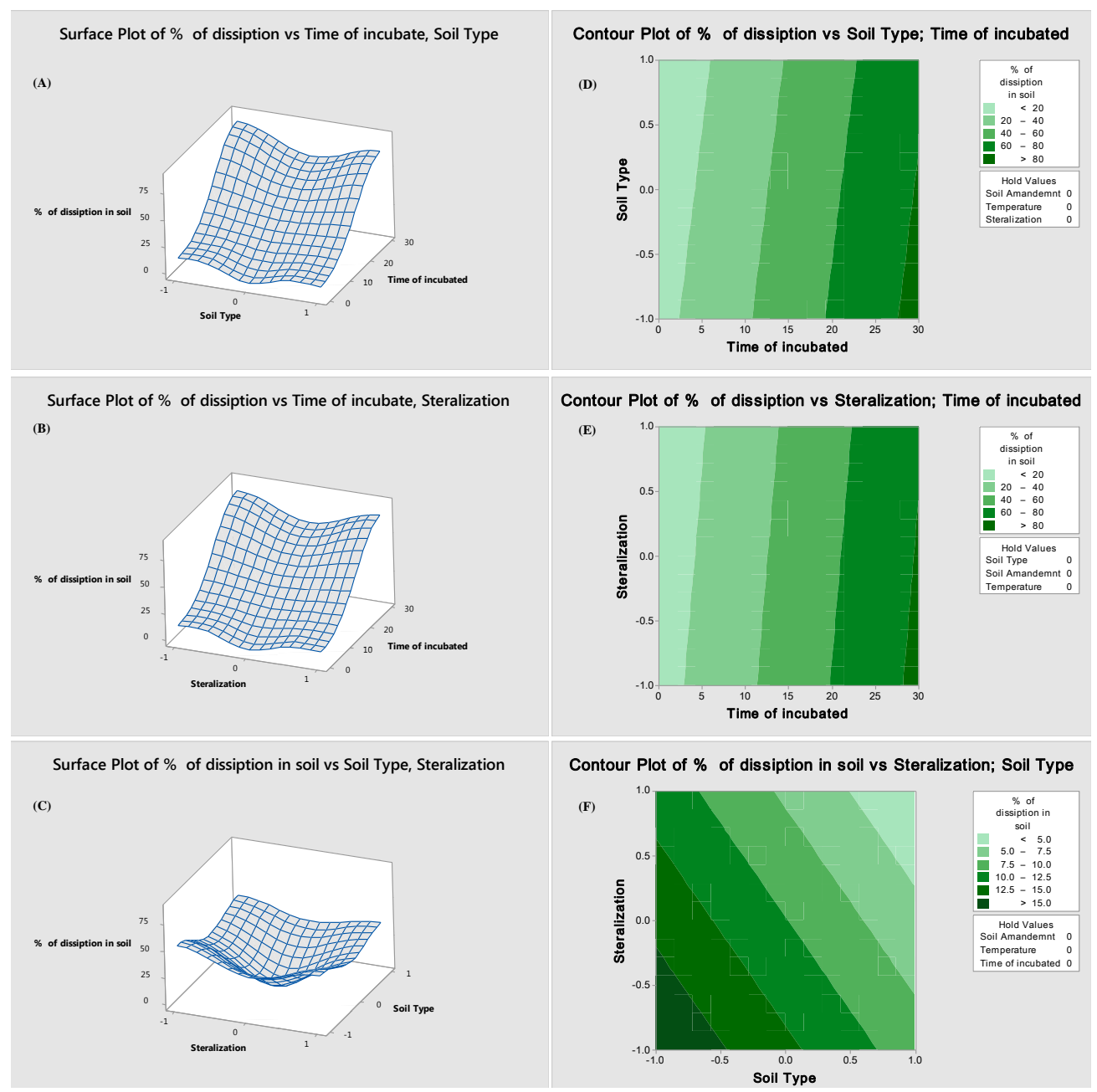

Figure 5. Surface plots and contour plots of CAP in soil A and B with or without wheat straw at deferent conditions depended on model 5

Table 8. Predicted dissipation (\%) of CAP using model 5 versus practical dissipation values in soil A and B at different time intervals

\begin{tabular}{|c|c|c|c|c|c|c|c|c|c|c|c|c|c|}
\hline \multirow{3}{*}{$\begin{array}{l}\text { Treat } \\
\text { ment }\end{array}$} & \multicolumn{13}{|c|}{ Dissipation (\%) at time } \\
\hline & \multicolumn{2}{|c|}{$\mathbf{0}$} & \multicolumn{2}{|c|}{3} & \multicolumn{2}{|c|}{7} & \multicolumn{2}{|c|}{10} & \multicolumn{2}{|c|}{15} & \multicolumn{2}{|c|}{30} & \multirow{2}{*}{\begin{tabular}{|c|}
60 \\
$\begin{array}{c}\text { Practi } \\
\text { cal }\end{array}$ \\
\end{tabular}} \\
\hline & \begin{tabular}{|c|}
$\begin{array}{c}\text { Theore } \\
\text { tical }\end{array}$ \\
\end{tabular} & $\begin{array}{c}\text { Practi } \\
\text { cal }\end{array}$ & $\begin{array}{c}\text { Theore } \\
\text { tical }\end{array}$ & $\begin{array}{c}\text { Practi } \\
\text { cal }\end{array}$ & $\begin{array}{c}\text { Theore } \\
\text { tical }\end{array}$ & $\begin{array}{c}\text { Practi } \\
\text { cal }\end{array}$ & $\begin{array}{c}\text { Theore } \\
\text { tical }\end{array}$ & $\begin{array}{c}\text { Practi } \\
\text { cal }\end{array}$ & $\begin{array}{c}\begin{array}{c}\text { Theore } \\
\text { tical }\end{array} \\
\end{array}$ & $\begin{array}{c}\text { Practi } \\
\text { cal }\end{array}$ & \begin{tabular}{|c|}
$\begin{array}{c}\text { Theore } \\
\text { tical }\end{array}$ \\
\end{tabular} & $\begin{array}{c}\text { Practi } \\
\text { cal }\end{array}$ & \\
\hline $\mathrm{T}_{1}$ & 16.8 & 11.3 & 24.0 & 31.2 & 33.4 & 57.7 & 40.6 & 73.5 & 52.4 & 85.7 & 88.0 & 88.8 & ND \\
\hline $\mathrm{T}_{2}$ & 12.2 & 9.8 & 19.3 & 25.6 & 28.8 & 55.5 & 35.9 & 60.6 & 47.8 & 80.2 & 83.4 & 85.0 & ND \\
\hline $\mathrm{T}_{3}$ & 10.6 & 8.6 & 17.7 & 31.5 & 27.2 & 47.1 & 34.3 & 55.6 & 46.2 & 76.0 & 81.8 & 83.2 & ND \\
\hline $\mathrm{T}_{4}$ & 10.6 & 11.1 & 17.7 & 35.8 & 27.2 & 53.1 & 34.3 & 62.5 & 46.2 & 75.9 & 81.8 & 83.0 & ND \\
\hline $\mathrm{T}_{5}$ & 17.9 & 18.6 & 25.0 & 38.2 & 34.5 & 53.4 & 41.6 & 61.5 & 53.5 & 75.2 & 89.0 & 82.4 & ND \\
\hline $\mathrm{T}_{6}$ & 11.9 & 7.9 & 19.1 & 34.1 & 28.5 & 46.6 & 35.7 & 55.8 & 47.5 & 69.3 & 83.1 & 82.1 & ND \\
\hline $\mathrm{T}_{7}$ & 3.6 & 5.3 & 10.7 & 9.1 & 20.2 & 46.9 & 27.3 & 61.7 & 39.2 & 70.7 & 74.8 & 79.1 & ND \\
\hline
\end{tabular}


Effect of Different Soil Treatments on Dissipation of Chlorantraniliprole and Dehydrogenase Activity Using Experimental Modeling Design

\begin{tabular}{|l|l|l|l|l|l|l|l|l|l|l|l|l|l|}
$\mathrm{T}_{8}$ & 8.0 & 13.4 & 15.1 & 18.2 & 24.6 & 52.1 & 31.7 & 62.6 & 43.6 & 74.6 & 79.1 & 79.7 & $\mathrm{ND}$ \\
\hline $\mathrm{T}_{9}$ & 9.3 & 16.0 & 16.4 & 18.5 & 25.9 & 43.5 & 33.0 & 58.1 & 44.9 & 71.3 & 80.4 & 78.3 & ND \\
\hline $\mathrm{T}_{10}$ & 2.3 & 3.5 & 9.4 & 22.6 & 18.9 & 44.3 & 26.0 & 51.8 & 37.9 & 69.0 & 73.4 & 75.6 & $\mathrm{ND}$ \\
\hline $\mathrm{T}_{11}$ & 9.5 & 14.0 & 16.7 & 37.2 & 26.1 & 47.7 & 33.3 & 68.2 & 45.1 & 72.6 & 80.7 & 86.2 & $\mathrm{ND}$ \\
\hline $\mathrm{T}_{12}$ & 8.2 & 6.8 & 15.4 & 23.0 & 24.8 & 38.2 & 32.0 & 52.6 & 43.8 & 76.1 & 79.4 & 80.0 & $\mathrm{ND}$ \\
\hline
\end{tabular}

Model 5: Dissipation $(\%)=10.09$ - 4.30 Soil type + 0.13 Soil amendment - 0.656 Temperature 2.972 Sterilization +2.3717 Time of incubation. None-detectable (ND).

From $\mathrm{t}_{0.5}$ values obtained by model 16 , was it can be noted this is high fitness between calculated and theoretically values by this model. The theoretical half-life of CAP obtained by model 16 in $\mathrm{T}_{1}$ to $\mathrm{T}_{6}$ ranged from 8.39-11.13 days for soil $\mathrm{A}$ and $\mathrm{T}_{7}$ to $\mathrm{T}_{12}$ ranged from 9.84 to 11.70 days for soil $\mathrm{B}$.

$$
\begin{gathered}
\mathrm{t}_{0.5}=\quad 9.863+0.285 \text { Soil type } \quad-0.931 \text { Soil Amendment }- \\
\text { 0.437 Temperature }-0.182 \text { Sterilization } \\
r^{2}=0.99 \text { and } s=2.34
\end{gathered}
$$

The results are in agreements with Deshpande et al who studied the optimization of dimethoate degradation by Brevundimonas sp. MCM B-427 using factorial design: with on interactive effects of environmental factors (Deshpande et al. 2004). Abdulra'uf and Tan studied multivariate study of parameters in the determination of pesticide residues in apple by headspace solid phase micro extraction coupled to gas chromatography-mass spectrometry using experimental factorial design (Abdulra'uf and Tan 2013). Carro and others studied microwave-assisted solvent extraction and gas chromatography ion trap mass spectrometry procedure for the determination of persistent organochlorine pesticides (POPs) in marine sediment using experimental factorial design (Carro et al. 2006).

\subsection{Effect of CAP on Soil DHase Activity}

The side-effect of CAP was carried out depending on the effect on soil DHase activity which can be considered as an indicator of the biological activity and microbial population. The results of DHase activity in soil A and B treated with CAP at different conditions are shown in Tables 9 and 10 , respectively. Generally, the enzyme activity [ $\mu$ mol triphenylformazan (TPF)/g soil/24 h] was significantly decreased in all treatments compared with the controls at all-time intervals. The result proved that the enzyme activity was significantly decreased at 1 and 3-day of incubation then it was gradually increased at 7,10,15 and 30 days of incubation. This finding is may be due to the increase of pesticide dissipation.

In soil $\mathrm{A}$, the enzyme activity significantly increased from $0.166-0.533 \mathrm{TPF} / \mathrm{g}$ soil/24 $\mathrm{h}$ for sterilized control however, the enzyme of control non-sterilized increased from (0.306 to $0.901 \mu \mathrm{mol} \mathrm{TPF} / \mathrm{g}$ soil/24 h). It can be noted that the treatment $\mathrm{T}_{1}$ (wheat straw, non-sterilized and incubated at $50^{\circ} \mathrm{C}$ ) and $\mathrm{T}_{5}$ (without wheat straw, non- sterilized and incubated at $25^{\circ} \mathrm{C}$ ) that were non- sterilized showed the highest activity in the DHase compared to the sterilized treatments $\left(\mathrm{T}_{2}, \mathrm{~T}_{3}, \mathrm{~T}_{4}\right.$ and $\mathrm{T}_{6}$ ). $\mathrm{T}_{4}$ (without wheat straw, sterilized and incubated at $\left.50^{\circ} \mathrm{C}\right)$ showed high inhibition of DHase (0.007-0.094 $\mu \mathrm{mol}$ $\mathrm{TPF} / \mathrm{g}$ soil $/ 24 \mathrm{~h}$ ) followed by $\mathrm{T}_{6}$ (without wheat straw, sterilized and incubated at $25^{\circ} \mathrm{C}$ ) $0.009-0.133$ $\mu \mathrm{mol} \mathrm{TPF} / \mathrm{g}$ soil $/ 24 \mathrm{~h}$. However, treatments of $\mathrm{T}_{1}$ and $\mathrm{T}_{5}$ showed the lowest enzyme inhibition among all treatments (0.083-0.494 and 0.104-0.568 $\mu \mathrm{mol} \mathrm{TPF} / \mathrm{g}$ soil/24 h, respectively).

Table 9. Side effect CAP on DHase activity in soil A

\begin{tabular}{|l|c|c|c|c|c|c|}
\hline \multirow{2}{*}{ Treatments } & \multicolumn{7}{|l|}{ Activity $(\boldsymbol{\mu m o l} \mathbf{~ T P F} / \mathbf{g}$ soil/24 h) \pm SE at time (day) } \\
\cline { 2 - 7 } & $\mathbf{1}$ & $\mathbf{3}$ & $\mathbf{7}$ & $\mathbf{1 0}$ & $\mathbf{1 5}$ & $\mathbf{3 0}$ \\
\hline Control sterile & $0.166^{\mathrm{b}} \pm 0.003$ & $0.165^{\mathrm{b}} \pm 0.000$ & $0.227^{\mathrm{c}} \pm 0.007$ & $0.347^{\mathrm{b}} \pm 0.013$ & $0.347^{\mathrm{c}} \pm 0.026$ & $0.533^{\mathrm{c}} \pm 0.00$ \\
\hline Control non-sterile & $0.306^{\mathrm{a}} \pm 0.026$ & $0.323^{\mathrm{a}} \pm 0.017$ & $0.398^{\mathrm{a}} \pm 0.013$ & $0.479^{\mathrm{a}} \pm 0.000$ & $0.586^{\mathrm{a}} \pm 0.054$ & $0.901^{\mathrm{a}} \pm 0.003$ \\
\hline $\mathrm{T}_{1}$ & $0.083^{\mathrm{d}} \pm 0.012$ & $0.075^{\mathrm{d}} \pm 0.004$ & $0.228^{\mathrm{c}} \pm 0.011$ & $0.260^{\mathrm{d}} \pm 0.004$ & $0.247^{\mathrm{d}} \pm 0.008$ & $0.494^{\mathrm{d}} \pm 0.020$ \\
\hline $\mathrm{T}_{2}$ & $0.008^{\mathrm{e}} \pm 0.000$ & $0.007^{\mathrm{e}} \pm 0.000$ & $0.013^{\mathrm{d}} \pm 0.002$ & $0.024^{\mathrm{e}} \pm 0.002$ & $0.096^{\mathrm{e}} \pm 0.003$ & $0.186^{\mathrm{e}} \pm 0.015$ \\
\hline $\mathrm{T}_{3}$ & $0.008^{\mathrm{e}} \pm 0.000$ & $0.007^{\mathrm{e}} \pm 0.001$ & $0.012^{\mathrm{d}} \pm 0.001$ & $0.022^{\mathrm{e}} \pm 0.001$ & $0.091^{\mathrm{e}} \pm 0.003$ & $0.160^{\mathrm{f}} \pm 0.031$ \\
\hline $\mathrm{T}_{4}$ & $0.007^{\mathrm{e}} \pm 0.001$ & $0.005^{\mathrm{e}} \pm 0.000$ & $0.010^{\mathrm{d}} \pm 0.000$ & $0.012^{\mathrm{f}} \pm 0.001$ & $0.069^{\mathrm{g}} \pm 0.003$ & $0.094^{\mathrm{h}} \pm 0.007$ \\
\hline $\mathrm{T}_{5}$ & $0.104^{\mathrm{c}} \pm 0.011$ & $0.103^{\mathrm{c}} \pm 0.004$ & $0.258^{\mathrm{b}} \pm 0.024$ & $0.282^{\mathrm{c}} \pm 0.008$ & $0.379^{\mathrm{b}} \pm 0.057$ & $0.568^{\mathrm{b}} \pm 0.036$ \\
\hline $\mathrm{T}_{6}$ & $0.009^{\mathrm{e}} \pm 0.001$ & $0.008^{\mathrm{e}} \pm 0.000$ & $0.011^{\mathrm{d}} \pm 0.000$ & $0.016^{\mathrm{f}} \pm 0.002$ & $0.080^{\mathrm{f}} \pm 0.015$ & $0.133^{\mathrm{g}} \pm 0.019$ \\
\hline
\end{tabular}

Values are mean of three replicates and given as mean \pm standard error. Different letters $(a-h)$ in columns indicate the range from higher to lower rank as significant differences according to the SNK test $(P \leq 0.05)$. 
Effect of Different Soil Treatments on Dissipation of Chlorantraniliprole and Dehydrogenase Activity Using Experimental Modeling Design

Table 10. Side effect CAP on DHase activity in soil B

\begin{tabular}{|l|c|c|c|c|c|c|}
\hline \multirow{2}{*}{ Treatments } & \multicolumn{7}{|l|}{ Activity $(\boldsymbol{\mu m o l ~ T P F} / \mathbf{g}$ soil/24 h) \pm SE at time (day) } \\
\cline { 2 - 7 } & $\mathbf{1}$ & $\mathbf{3}$ & $\mathbf{7}$ & $\mathbf{1 0}$ & $\mathbf{1 5}$ & $\mathbf{3 0}$ \\
\hline Control sterile & $0.169^{\mathrm{e}} \pm 0.007$ & $0.140^{\mathrm{e}} \pm 0.017$ & $0.218^{\mathrm{d}} \pm 0.008$ & $0.323^{\mathrm{d}} \pm 0.004$ & $0.355^{\mathrm{c}} \pm 0.034$ & $0.509^{\mathrm{b}} \pm 0.021$ \\
\hline Control non-sterile & $0.266^{\mathrm{a}} \pm 0.017$ & $0.305^{\mathrm{a}} \pm 0.025$ & $0.376^{\mathrm{a}} \pm 0.004$ & $0.458^{\mathrm{a}} \pm 0.017$ & $0.523^{\mathrm{a}} \pm 0.003$ & $0.817^{\mathrm{a}} \pm 0.017$ \\
\hline $\mathrm{T}_{7}$ & $0.007^{\mathrm{g}} \pm 0.001$ & $0.004^{\mathrm{g}} \pm 0.000$ & $0.012^{\mathrm{f}} \pm 0.002$ & $0.065^{\mathrm{f}} \pm 0.003$ & $0.093^{\mathrm{g}} \pm 0.007$ & $0.188^{\mathrm{g}} \pm 0.013$ \\
\hline $\mathrm{T}_{8}$ & $0.146^{\mathrm{f}} \pm 0.001$ & $0.078^{\mathrm{f}} \pm 0.002$ & $0.139^{\mathrm{e}} \pm 0.008$ & $0.223^{\mathrm{e}} \pm 0.040$ & $0.201^{\mathrm{f}} \pm 0.019$ & $0.272^{\mathrm{f}} \pm 0.015$ \\
\hline $\mathrm{T}_{9}$ & $0.184^{\mathrm{c}} \pm 0.008$ & $0.182^{\mathrm{c}} \pm 0.001$ & $0.280^{\mathrm{b}} \pm 0.009$ & $0.385^{\mathrm{c}} \pm 0.079$ & $0.305^{\mathrm{d}} \pm 0.023$ & $0.458^{\mathrm{d}} \pm 0.016$ \\
\hline $\mathrm{T}_{10}$ & $0.006^{\mathrm{g}} \pm 0.000$ & $0.003^{\mathrm{g}} \pm 0.001$ & $0.011^{\mathrm{f}} \pm 0.000$ & $0.059^{\mathrm{g}} \pm 0.003$ & $0.076^{\mathrm{h}} \pm 0.006$ & $0.179^{\mathrm{h}} \pm 0.012$ \\
\hline $\mathrm{T}_{11}$ & $0.195^{\mathrm{b}} \pm 0.018$ & $0.191^{\mathrm{b}} \pm 0.016$ & $0.280^{\mathrm{b}} \pm 0.007$ & $0.416^{\mathrm{b}} \pm 0.036$ & $0.475^{\mathrm{b}} \pm 0.002$ & $0.476^{\mathrm{c}} \pm 0.030$ \\
\hline $\mathrm{T}_{12}$ & $0.171^{\mathrm{d}} \pm 0.007$ & $0.169^{\mathrm{d}} \pm 0.036$ & $0.264^{\mathrm{c}} \pm 0.002$ & $0.384^{\mathrm{c}} \pm 0.010$ & $0.276^{\mathrm{e}} \pm 0.003$ & $0.410^{\mathrm{e}} \pm 0.000$ \\
\hline
\end{tabular}

Values are mean of three replicates and given as mean \pm standard error. Different letters (a-h) in columns indicate the range from higher to lower rank as significant differences according to the SNK test $(P \leq 0.05)$.

In soil B the enzyme activity significantly increased from 0.169 to $0.509 \mu \mathrm{mol} \mathrm{TPF} / \mathrm{g}$ soil $/ 24 \mathrm{~h}$ for sterilized control however, the enzyme of non-sterilized control increased from $(0.266$ to $0.817 \mu \mathrm{mol}$ $\mathrm{TPF} / \mathrm{g}$ soil/24 h). In soil $\mathrm{B}$, it can be noted that the treatment of $\mathrm{T}_{8}$ (without wheat straw, nonsterilized and incubated at $50^{\circ} \mathrm{C}$ ), $\mathrm{T}_{12}$ (wheat straw, non-sterilized and incubated at $50^{\circ} \mathrm{C}$ ), $\mathrm{T}_{9}$ (without wheat straw, non-sterilized and incubated at $25^{\circ} \mathrm{C}$ ) and $\mathrm{T}_{11}$ (wheat straw, non-sterilized and incubated at $\left.25^{\circ} \mathrm{C}\right)$ that were non-sterilized showed the highest activity compared to the sterilized treatments $\left(\mathrm{T}_{7}\right.$ and $\mathrm{T}_{10}$ ). $\mathrm{T}_{7}$ (wheat straw, sterilized and incubated at $25^{\circ} \mathrm{C}$ ) indicated high inhibition (0.007-0.188 $\mu \mathrm{mol} \mathrm{TPF} / \mathrm{g}$ soil $/ 24 \mathrm{~h}$ ) followed by $\mathrm{T}_{10}$ (wheat straw, sterilized and incubated at $50^{\circ} \mathrm{C}$ ). However, treatments of $\mathrm{T}_{8}, \mathrm{~T}_{9}, \mathrm{~T}_{11}$ and $\mathrm{T}_{12}$ showed the lowest enzyme inhibition with in all treatments $(0.171$ $0.476 \mu \mathrm{mol} \mathrm{TPF} / \mathrm{g}$ soil/24 h).

The enzymes play an important role in the life process of microorganisms in the soil. Although a few enzymes can only function within a viable cell DHase (Dick 1994). Studies of enzyme activities in soil are important as they indicate the potential of the soil to support biochemical processes Soil dehydrogenase activity is often used as a measure of any disruption caused by pesticides, trace elements or management (Brzezińska et al. 1998; Naré et al. 2014). A laboratory study was conducted to examine the effects of five insecticides on microbial and enzymatic activities important to fertility in sandy soil ( $\mathrm{Tu}$ 1995). The authors reported a formazan formation resulting from DHase activity was significantly greater with tebupirimphos and Aztec for one week. Although short-lived inhibitory effects on activities of microbes and enzymes were caused by the insecticides, the soil indigenous microbes can tolerate the chemicals used for control of soil pests (Tu 1995). Gundi and other applied three insecticides, monocrotophos, quinalphos, and cypermethrin at $0,5,10$, and $25 \mu \mathrm{g} / \mathrm{g}$ either singly or in combination to a black clay soil to investigate their effects on the soil microflora and DHase activity (Gundi et al. 2005). All three insecticides significantly enhanced the proliferation of bacteria and fungi and the soil DHase activity even at the highest level of $25 \mu \mathrm{g} / \mathrm{g}$. Monocrotophos or quinalphos in combination with cypermethrin at tested levels interacted significantly to yield additive, synergistic, and antagonistic responses toward bacteria and fungi and DHase activity in soil. Antagonistic interactions were more pronounced toward soil microflora and DHase activity when the two insecticides (monocrotophos or quinalphos + cypermethrin) were present together in the soil at highest level $(25+25 \mu \mathrm{g} / \mathrm{g})$, whereas synergistic or additive responses occurred at lower level with the same combination of insecticides in soil (Gundi et al. 2005). Durmuș and co-author studied the effects of the kombucha and lyophilized waste of kombucha culture on wheat plant yield, DHase and catalase enzyme activity of soils (Durmuș and Kızılkaya 2016). At the end of the greenhouse experiment, it was observed that increases in the amount of kombucha and lyophilized waste of kombucha culture increased wheat yield and also caused an improvement of DHase and catalase enzyme activity of soils depending on the soil texture. Moreover, it is concluded that the improvements of the soil biological characteristics was more significant for sandy loamy soil than the loamy soil (Durmuș and Kızılkaya 2016). Tan and other studied differences in the response of soil DHase activity to Cd contamination (Tan et al. 2017). This study showed that the 2-p-iodophenyl-3 pnitrophenyl-5 tetrazolium chloride (INT) assay is more sensitive to determine DHase than the triphenyltetrazolium chloride (TTC) procedure under optimal conditions. It is evident that (INT) was the optimal substrate to measure DHase in soil. A significant correlation was obtained between 
specific DHase-TTC and DHase-INT, revealing that soil properties were one of the factors influencing the determination of dehydrogenase. In general, the specific enzymatic activities were striking and useful to delimit differences between the two methods, and reflect similar changes in various soils (Tan et al. 2017).

\section{CONCLUSION}

Under tropical conditions, the dissipation and degradation of pesticides in the soil are related to soil properties and natural conditions. The results showed that the dissipation of CAP insecticide was initially rapid and incresed with time increase. The dissipation kinetics of CAP can be described by first-order kinetic, and the half-life was found to be ranged from 7.52 to 11.55 days in Alluvial soil (A) and from 9.01 to 11.63 days in Calcareous soil (B), respectively. CAP dissipated rapidly in soil A compared to the soil $\mathrm{B}$. The developed model $\left(\mathrm{t}_{0.5}\right.$, days $=9.863+0.285$ Soil type 0.931 Soil Amendment - 0.437 Temperature - 0.182 Sterilization) could indeed be used to estimate the half-life of the CAP at $95 \%$ confidence level. This model would predict or estimate the half-life of CAP or any of the CAP family. From the present study it was concluded that CAP dissipation is fast in soil. So this pesticide can be used in limited dosage and has great potential to be a better alternative for highly toxic organochlorine, organophsphorous, and pyrethroid.

\section{REFERENCES}

Abdulra'uf LB, Tan GH (2013) Multivariate study of parameters in the determination of pesticide residues in apple by headspace solid phase microextraction coupled to gas chromatography-mass spectrometry using experimental factorial design. Food Chemistry 141(4):4344-4348

Adinarayana K, Ellaiah P (2002) Response surface optimization of the critical medium components for the production of alkaline protease by a newly isolated Bacillus sp. Journal of pharmacy \& pharmaceutical sciences : a publication of the Canadian Society for Pharmaceutical Sciences, Societe canadienne des sciences pharmaceutiques 5(3):272-280

Anastassiades M, Lehotay SJ, Štajnbaher D, Schenck FJ (2003) Fast and easy multiresidue method employing acetonitrile extraction/partitioning and "dispersive solid-phase extraction" for the determination of pesticide residues in produce. Journal of AOAC International 86(2):412-431

Bajeer MA, Mallah MA, Sherazi STH, Bhanger MI, Nizamani SM (2016) Investigation of dissipation, adsorption, degradation, and leaching of triazophos pesticide in various soils. Polycyclic Aromatic Compounds 36(3):229-241

Bassi A, Alber R, Wiles J, Rison J, Frost N, Marmor F, Marcon P Chlorantraniliprole: A novel anthranilic diamide insecticide. In: XVI International Plant Protection Congress, 2007. vol 2007. p 52-59

Box GE, Behnken DW (1960) Some new three level designs for the study of quantitative variables. Technometrics 2(4):455-475

Brugger KE, Cole PG, Newman IC, Parker N, Scholz B, Suvagia P, Walker G, Hammond TG (2010) Selectivity of chlorantraniliprole to parasitoid wasps. Pest Managment Science 66(10):1075-1081

Brzezińska M, Stępniewska Z, Stępniewski W (1998) Soil oxygen status and dehydrogenase activity. Soil Biology and Biochemistry 30(13):1783-1790

Burr JT (1990) The tools of quality. 6. Pareto charts. Quality Progress 23(11):59-61

Cameron RA, Williams CJ, Portillo HE, Marçon PC, Teixeira LA (2015) Systemic application of chlorantraniliprole to cabbage transplants for control of foliar-feeding lepidopteran pests. Crop Protection 67:13-19

Carro N, Garcia I, Ignacio M, Mouteira A (2006) Microwave-assisted solvent extraction and gas chromatography ion trap mass spectrometry procedure for the determination of persistent organochlorine pesticides (POPs) in marine sediment. Analytical and Bioanalytical Chemistry 385(5):901-909

Casida Jr L, Klein D, Santoro T (1964) Soil dehydrogenase activity. Soil Science 98(6):371-376

Deshpande N, Sarnaik S, Paranjpe S, Kanekar P (2004) Optimization of dimethoate degradation by Brevundimonas sp. MCM B-427 using factorial design: studies on interactive effects of environmental factors. World Journal of Microbiology and Biotechnology 20(5):455-462

Dick RP (1994) Soil enzyme activities as indicators of soil quality. Defining Soil Quality for A Sustainable Environment(definingsoilqua):107-124

Dong F, Xu J, Liu X, Li J, Li Y, Kong Z, Shan W, Zheng Z, Zheng Y (2011) Determination of chlorantraniliprole residues in corn and soil by UPLC-ESI-MS/MS and its application to a pharmacokinetic study. Chromatographia 74(5-6):399-406 
Durmuş M, Kızılkaya R (2016) Effect of Kombu tea (Kombucha) and mix microorganisms culture of Kombu tea production waste on wheat plant yield, dehydrogenase and catalase enzyme activity of soils. Toprak Bilimi ve Bitki Besleme Dergisi 4(2):76-82

El-Sebae A (1989) Fate and undesirable effects of pesticides in Egypt. Ecotoxicology and Climate 359-371

Estes S, Lynch M (2003) Rapid fitness recovery in mutationally degraded lines of Caenorhabditis elegans. Evolution 57(5):1022-1030

Fletcher CL, Kaufman DD (1980) Effect of sterilization methods on 3-chloroaniline behaviour in soil. Journal of Agricultural and Food Chemistry 28(3):667-671

Fogg P, Boxall AB, Walker A (2003) Degradation of pesticides in biobeds: the effect of concentration and pesticide mixtures. Journal of Agriculture and Food Chemistry 51(18):5344-5249

Gavrilescu M (2005) Fate of pesticides in the environment and its bioremediation. Engineering in Life Sciences 5(6):497-526

Gee GW, Bauder JW, Klute A (1986) Particle-size analysis. Methods of soil analysis Part 1 Physical and mineralogical methods:383-411

Gundi VA, Narasimha G, Reddy BR (2005) Interaction effects of insecticides on microbial populations and dehydrogenase activity in a black clay soil. Journal of Environmental Science and Health, Part B 40(2):269-283

Johnson RM, Pepperman AB (1995) Analysis of metribuzin and associated metabolites in soil and water samples by solid phase extraction and reversed phase thin layer chromatography. Journal of Liquid Chromatography \& Related Technologies 18(4):739-753

Kadiyala A, Kumar A (2008) Application of CART and Minitab software to identify variables affecting indoor concentration levels. Environmental Progress 27(2):160-168

Khan S, Manchur A (2017) Activated cow-dung slurry as a tool of pesticides bioremediation. Journal of Microbiology and Biotechnology Research 5(2):12-17

Khan SU (2016) Pesticides in the soil environment. Elsevier

Khay S, Choi JH, Abd El-Aty AM, Mamun MI, Park BJ, Goudah A, Shin HC, Shim JH (2008) Dissipation behavior of lufenuron, benzoylphenylurea insecticide, in/on Chinese cabbage applied by foliar spraying under greenhouse conditions. Bulletin of Environmental Contamination and Toxicology 81(4):369-372

Kookana RS (2010) The role of biochar in modifying the environmental fate, bioavailability, and efficacy of pesticides in soils: a review. Soil Research 48(7):627-637

Lavtižar V (2015) Environmental stability and toxicity assessment of chlorantraniliprole and its derivatives: dissertation. Univerza v Novi Gorici, Fakulteta za podiplomski študij

Malhat F, Abdallah H, Hegazy I (2012) Dissipation of chlorantraniliprole in tomato fruits and soil. Bulletin of Environmental Contamination and Toxicology 88(3):349-351

Malhat FM (2012) Determination of chlorantraniliprole residues in grape by high-performance liquid chromatography. Food Analytical Methods 5(6):1492-1496

Mansour SA (2004) Pesticide exposure-Egyptian scene. Toxicology 198(1):91-115

Mariusz C, Agnieszka ZM, Marcin W, Zofia PS (2013) Biodegradation and bioremediation potential of diazinon-degrading Serratia marcescens to remove other organophosphorus pesticides from soils. Journal of Environmental Management 117:7-16

Mountacer H, Atifi A, Wong-Wah-Chung P, Sarakha M (2014) Degradation of the pesticide carbofuran on clay and soil surfaces upon sunlight exposure. Environmental Science and Pollution Research 21(5):3443-3451

Myers RH, Montgomery DC, Anderson-Cook CM (2016) Response surface methodology: process and product optimization using designed experiments. John Wiley \& Sons

Nadelhoffer K, Giblin A, Shaver G, Laundre J (1991) Effects of temperature and substrate quality on element mineralization in six arctic soils. Ecology 72(1):242-253

Naré R, Savadogo P, Gnankambary Z, Nacro H, Sedogo P (2014) Effect of three pesticides on soil dehydrogenase and fluorescein diacetate activities in vegetable garden in Burkina Faso. Current Research Journal of Biological Sciences 6(2):102-106

Nelson DW, Sommers LE, Sparks D, Page A, Helmke P, Loeppert R, Soltanpour P, Tabatabai M, Johnston C, Sumner M (1996) Total carbon, organic carbon, and organic matter. Methods of Soil Analysis Part 3Chemical Methods:961-1010

Pal R, Chakrabarti K, Chakraborty A, Chowdhury A (2010) Degradation and effects of pesticides on soil microbiological parameters-a review. International Journal of Agricultural Research 5(8):625-643

Ramasubramanian T, Paramasivam M, Salin KP, Jayanthi R (2012) Dissipation kinetics of chlorantraniliprole in soils of sugarcane ecosystem. Bulletin of Environmental Contamination and Toxicology 89(6):1268-1271

Reh FJ (2005) Pareto's principle-The 80-20 rule. Business Credit-New York Then Columbia Md 107(7):76 
Satyanarayan S, Murkute P (2008) Biogas production enhancement by Brassica compestries amendment in cattle dung digesters. Biomass and Bioenergy 32(3):210-215

Scholz-Starke B, Egerer S, Schäffer A, Toschki A, Roßig M (2017) Higher-tier Multi-species Studies in Soil: Prospects and Applications for the Environmental Risk Assessment of Pesticides Ecotoxicology and Genotoxicology. p 31-58

Sharma AK, Zimmerman WT, Singles SK, Malekani K, Swain S, Ryan D, Mcquorcodale G, Wardrope L (2014a) Photolysis of chlorantraniliprole and cyantraniliprole in water and soil: verification of degradation pathways via kinetics modeling. Journal of Agricultural and Food Chemistry 62(28):6577-6584

Sharma N, Mandal K, Kumar R, Kumar B, Singh B (2014b) Persistence of chlorantraniliprole granule formulation in sugarcane field soil. Environmental Monitoring and Assessment 186(4):2289-2295

Sharom MS, Stephenson G (1976) Behavior and fate of metribuzin in eight Ontario soils. Weed Science:153160

Singh J, Singh DK (2005) Dehydrogenase and phosphomonoesterase activities in groundnut (Arachis hypogaea L.) field after diazinon, imidacloprid and lindane treatments. Chemosphere 60(1):32-42

Singh R, Varshney K, Rani S (1985) Adsorption thermodynamics of carbofuran on sandy clay loam and silt loam soils. Ecotoxicology and Environmental Safety 10(3):309-313

Solanki AB, Parikh JR, Parikh RH (2007) Formulation and optimization of piroxicam proniosomes by 3-factor, 3-level Box-Behnken design. AAPS PharmSciTech 8(4):43-49

Stepniewska Z, Wolinska A, Lipinska R (2007) Effect of fonofos on soil dehydrogenase activity. International Agrophysics 21(1):101-105

Tabatabai M (1994) Soil enzymes. Methods of Soil Analysis: Part 2-Microbiological and Biochemical Properties(methodsofsoilan2):775-833

Tan X, Liu Y, Yan K, Wang Z, Lu G, He Y, He W (2017) Differences in the response of soil dehydrogenase activity to $\mathrm{Cd}$ contamination are determined by the different substrates used for its determination. Chemosphere 169:324-332

Tomkiel M, Wyszkowska J, Kucharski J, Baćmaga M, Borowik A (2014) Response of microorganisms and enzymes to soil contamination with the herbicide Successor T 550 SE. Environment Protection Engineering 40:15-27

Tu C (1995) Effect of five insecticides on microbial and enzymatic activities in sandy soil. Journal of Environmental Science \& Health Part B 30(3):289-306

Vijayasree V, Bai H, Beevi SN, Mathew TB, Kumar V, George T, Xavier G (2013) Persistence and effects of processing on reduction of chlorantraniliprole residues on cowpea fruits. Bulletin of Environmental Contamination and Toxicology 90(4):494-498

Wang D, Zhang K (2017) Determination of the dissipation dynamics and residue behaviors of chlorantraniliprole in sugarcane and soil by LC- MS/MS. Environmental Monitoring and Assessment 189(8):372

Wu D, Zhou J, Li Y (2009) Effect of the sulfidation process on the mechanical properties of a CoMoP/Al 2 O 3 hydrotreating catalyst. Chemical Engineering Science 64(2):198-206

Xu P, Ren Y, Zhou Z, Liu A, Zhang H (2010) Determination of chlorantraniliprole in vegetables, fruits and grains by SPE clean-up and LC-UV. Chromatographia 72(7-8):763-766

Zhang J-M, Chai W-G, Wu Y-L (2012) Residues of chlorantraniliprole in rice field ecosystem. Chemosphere 87(2):132-136

Citation: M. Badawy et al., "Effect of Different Soil Treatments on Dissipation of Chlorantraniliprole and Dehydrogenase Activity Using Experimental Modeling Design", International Journal of Advanced Research in Chemical Science (IJARCS), vol. 4, no. 12, pp. 7-23, 2017.

Copyright: (C) 2017 Authors. This is an open-access article distributed under the terms of the Creative Commons Attribution License, which permits unrestricted use, distribution, and reproduction in any medium, provided the original author and source are credited. 